\title{
Redes Transnacionails de Advocacia Pública: Estratégias e Impactos - 0 Projeto Planafloro e o Painel de Inspeção do Banco Mundial*
}

Maria Guadalupe Moog Rodrigues

Em julho de 1995, organizações da sociedade civil do estado amazônico de Rondônia apresentaram ao Painel de Inspeção um pedido de investigação do projeto Planafloro. O Painel de Inspeção, criado em 1994, é um mecanismo independente que investiga acusações de violação pelo Banco Mundial de suas próprias políticas internas. Nesse caso, essas organizações rondonienses acusaram o Banco de exercer um monitoramento inadequado sobre o projeto. Decorridos três anos do início de sua execução, o Planafloro, iniciativa que visa melhorar o manejo de recursos naturais em Rondônia, não lograra alcançar praticamente nenhum de seus objetivos ambientais. O Banco, no entanto, continuava a liberar regularmente os desembolsos previstos originalmente para o projeto.

\footnotetext{
*Este artigo é parte de um projeto, sob a coordenação de Jonathan Fox, Kay Treakle e Dana Clark, intitulado "Demanding Accountability: Lessons from the World Bank Inspection Panel". O projeto inclui a publicação de um livro com análises sobre os diversos pedidos de investigação de projetos pelo Painel de Inspeção, e iniciativas de advocacia visando disseminar informações sobre o mecanismo, suas possibilidades e as dificuldades em acioná-lo.
}

CONTEXTO INTERNACIONAL Rio de Janeiro, vol. 24, n1, janeiro/junho 2002, pp. 73-128. 
O pedido de investigação do Planafloro ao Painel de Inspeção não foi simplesmente um artifício técnico destinado a forçar o Banco a melhorar o monitoramento do projeto com base em seus próprios "padrões de qualidade". Tratou-se, primordialmente, de uma estratégia eficaz no conflito de interesses que contrapunha, desde a época da formulação do Planafloro, organizações civis ao governo do estado. Enquanto setores da sociedade civil criticavam o governo por sua negligência nas medidas de cunho ambiental do projeto, o governo estadual acusava grupos da sociedade civil de criar obstáculos ao desenvolvimento sustentável do estado que o Planafloro ajudaria a promover.

A estratégia de demandar a investigação do Planafloro pelo Painel de Inspeção tornou-se um marco histórico na evolução das relações entre governo e sociedade civil em Rondônia, tendo produzido efeitos imediatos e de longo prazo, não apenas sobre o projeto, mas também na balança de poder entre as forças políticas locais.

Neste artigo, devido a limitações de espaço, abordo os problemas de execução do Planafloro apenas de forma indireta. Minha atenção estará voltada para a mobilização política que tais problemas geraram, dentro e fora de Rondônia, e, particularmente, para o papel do pedido de investigação do Planafloro nesse processo.

A história do pedido de investigação do Planafloro ilustra o aumento gradual da capacidade política (empowerment) de grupos da sociedade civil rondoniense. Esse processo ocorreu em um contexto político caracterizado pela fraqueza das instituições democráticas locais e pelo controle das elites políticas sobre os recursos públicos do estado. Apesar de o pedido de investigação ter se tornado um divisor de águas nas relações entre o estado e a sociedade local, ele não pode ser analisado isoladamente. Na verdade, o pedido inseriu-se em um conjunto de iniciativas organizadas por uma rede transnacional de advocacia pública constituída por grupos e indivíduos em Rondônia, no Brasil e no exterior preocupados com problemas ambientais em Rondônia. A mobilização orquestrada por essa rede transnacional data de 
Redes Transnacionais de Advocacia Pública: O Projeto Planafloro...

meados da década de 80, quando ativistas começaram a reagir à devastação ambiental causada pela pavimentação da BR-364 - que liga Cuiabá, em Mato Grosso, a Porto Velho, em Rondônia - e ao estabelecimento de projetos de assentamento na floresta tropical. Tais iniciativas constituíram a essência do programa Polonoroeste (Programa Integrado de Desenvolvimento da Região Noroeste), executado entre 1983 e 1987 e financiado, em sua maior parte, por um empréstimo do Banco Mundial ao governo brasileiro ${ }^{1}$.

O estudo de mobilizações transnacionais em torno de questões ambientais locais é particularmente relevante em um momento em que a maioria dos países, e praticamente todos os setores da sociedade doméstica, estão sendo afetados por processos de globalização econômica, política e cultural. O pedido de investigação do Planafloro pelo Painel de Inspeção ilustra a dinâmica mediante a qual redes transnacionais de advocacia pública influenciam, simultaneamente, políticas ambientais locais, domésticas e internacionais. Para efeitos deste estudo, redes transnacionais de advocacia pública são definidas de acordo com os critérios apresentados por Keck e Sikkink (1998): elas são redes de atores políticos (indivíduos, ONGs, associações de base, institutos de pesquisa, e até mesmo setores de agências governamentais e multilaterais) que se mobilizam em torno de um assunto de interesse comum. Membros da rede compartilham valores, um mesmo discurso, informações e serviços. A flexibilidade organizacional dessas redes, sua capacidade de produzir e disseminar informações e de operar simultaneamente em países distintos e em diversas arenas políticas - locais, domésticas e internacionais - são vantagens importantes no cenário da política ambiental internacional.

A despeito dos inúmeros méritos das redes transnacionais de advocacia pública, é importante ressaltar que estas também apresentam limitações. Infelizmente, os estudiosos do assunto têm prestado pouca atenção a tais limites. Por exemplo, um dos pressupostos da literatura sobre redes transnacionais de advocacia pública é que estas, necessa- 
riamente, contribuem para o aumento da capacidade política dos atores locais que delas participam (Princen, 1994; Jordan e Van Tuijl, 2000; Jezic, 2001). Uma análise dos esforços da rede transnacional de advocacia pública que se constituiu em torno das questões ambientais em Rondônia, e em particular do pedido de investigação do Planafloro, demonstra que esse pressuposto carece de refinamento teórico. Na verdade, os ganhos políticos que grupos locais obtiveram em função de sua participação na rede transnacional foram acompanhados de uma demanda crescente sobre as capacidades técnica e política desses grupos. No entanto, nem a rede transnacional como um todo, nem as próprias organizações locais foram inteiramente capazes de responder a tais demandas. O resultado, no longo prazo, foi o comprometimento relativo do espaço político que as organizações da sociedade civil rondoniense conquistaram imediatamente após a apresentação do pedido de investigação ao Painel.

À luz do exemplo oferecido pela política rondoniense na última década, proponho uma maior cautela da parte de ativistas e estudiosos de iniciativas de cooperação transnacional e advocacia pública em questões de desenvolvimento auto-sustentável. É verdade que a participação de atores locais em redes transnacionais de advocacia pública tende a aumentar a capacidade política destes. No entanto, não está claro até que ponto esse é um processo estrutural ou conjuntural. O objetivo deste artigo é distinguir entre esses dois resultados possíveis, além de discutir as condições sob as quais a capacitação política de grupos locais em decorrência da participação em redes transnacionais pode ser mantida - e aprofundada - no longo prazo.

Esta discussão, porém, pode se tornar irrelevante caso o conceito de capacitação (ou capacidade) política de grupos locais não esteja claramente definido. Além disso, tal processo deve ser avaliado não só em termos das oportunidades, mas também dos limites à atuação dos grupos da sociedade civil em relação aos tradicionais interesses dominantes locais. Nesse sentido, a história das tensões em torno das 
Redes Transnacionais de Advocacia Pública: O Projeto Planafloro...

políticas de desenvolvimento e de proteção ambiental em Rondônia nos últimos anos parece referendar, em um primeiro momento, o pressuposto teórico de que grupos locais se beneficiam politicamente de sua participação em redes transnacionais de advocacia. De fato, certas organizações da sociedade civil rondoniense adquiriram, em anos recentes, a posição de interlocutores legítimos da sociedade civil junto ao estado; aumentaram sua capacidade de obter e disseminar informações sobre políticas públicas; garantiram - mediante pressão e/ou diálogo - a execução de medidas emergenciais de proteção ao meio ambiente e a populações indígenas locais; inviabilizaram legalmente tentativas do governo de reverter ganhos ambientais; e, finalmente, foram capazes de conquistar acesso direto a recursos financeiros relacionados ao Planafloro e que estavam originalmente sob absoluto controle de agências governamentais locais. Além disso, grupos da sociedade civil local aumentaram sua compreensão dos processos de formulação de políticas públicas em Rondônia e das inter-relações existentes entre as dinâmicas de desenvolvimento e sustentabilidade ambiental. $\mathrm{O}$ que tal pressuposto negligencia, no entanto, é o reconhecimento de que tais conquistas continuam sendo relativas. Em termos absolutos, como já foi ressaltado por Keck $(1998)^{2}$, as organizações da sociedade civil de Rondônia não têm sido capazes de opor resistência efetiva ao modelo de desenvolvimento patrocinado pelas elites políticas no estado. Neste artigo, além de reconhecer as vantagens políticas da participação de grupos locais em redes transnacionais de advocacia, discuto os limites dessa opção e sugiro alternativas.

Ainda em termos teóricos, é importante ressaltar uma vantagem adicional do estudo do pedido de investigação do Planafloro pelo Painel de Inspeção. Este colocou em questão a natureza e a eficácia do principal mecanismo vigente de prestação de contas das instituições financeiras multilaterais à sociedade civil global. O pedido de investigação do Planafloro revelou que o Painel não pode ser considerado uma entidade à parte de seu contexto político-institucional. Na reali- 
dade, o Painel não é apenas uma resposta institucional (e, em princípio, politicamente neutra) a campanhas transnacionais por um maior controle público sobre as operações de organismos multilaterais ${ }^{3}$. Este estudo irá demonstrar que, ao contrário, o Painel é mais uma arena de conflito político onde tais campanhas transnacionais continuam a se desenrolar. Por se tratar de uma arena política, o Painel de Inspeção não pode e não irá se despolitizar, a despeito de vários esforços nesse sentido, tanto da parte do Banco quanto da sociedade civil internacional. A ONG internacional Center for International Environmental Law (CIEL), por exemplo, tem realizado inúmeras campanhas visando aumentar o nível de independência do Painel com relação ao Banco Mundial ${ }^{4}$. Diretores do Banco, por sua vez, têm procurado alterar os limites de competência do Painel para que este se restrinja a questões técnicas referentes aos projetos e ignore as consequiências sociais e políticas destes.

Se o Painel de Inspeção é, de fato, mais uma arena onde confrontos políticos se desenrolam, é importante levar em conta as consequiências de uma estratégia que leva a uma instância internacional um conflito político que envolve, essencialmente, questões locais. O estudo do pedido de investigação do Planafloro permite tais considerações na medida em que ilustra a tendência de determinados confrontos políticos modernos se desenrolarem, simultaneamente, em diversos planos de análise: local, nacional e internacional (Rosenau, 1993; Lipschutz e Mayer, 1996; O’Brien et alii, 2000). Nesse sentido, este artigo procura discutir o impacto do pedido de investigação do Planafloro nesses três níveis. Na primeira parte, descrevo as origens do pedido. Atenção especial é dada ao papel desempenhado por essa estratégia nos processos de "renovação das energias" da rede transnacional de advocacia em torno do Planafloro e de realinhamento das forças políticas no seu interior. Na segunda parte, discuto as reações do Banco Mundial e dos governos brasileiro e rondoniense ao pedido, bem como os impactos imediatos e de longo prazo deste sobre os contextos político e ambiental de Rondônia. Finalmente, em minhas conclusões, reflito sobre as 
Redes Transnacionais de Advocacia Pública: O Projeto Planafloro...

consequiências institucionais do pedido de investigação do Planafloro em três níveis: internacional, para a legitimidade do Painel de Inspeção; nacional, para a consolidação de esforços de advocacia que demandam uma maior transparência na formulação de políticas públicas no Brasil; e no nível local, para a sustentabilidade política das organizações da sociedade civil rondoniense.

Em termos metodológicos, esta pesquisa contou com informações obtidas a partir de trinta entrevistas com ativistas brasileiros e internacionais nas áreas de meio ambiente e direitos humanos, funcionários dos governos brasileiro e rondoniense, funcionários do Banco Mundial e consultores independentes. No texto, a identidade dos entrevistados é protegida por pseudônimos. As entrevistas foram conduzidas no Brasil (Porto Velho, Brasília, São Paulo e Rio de Janeiro) e nos Estados Unidos (Washington, D.C.) em duas ocasiões (1994 e 2000). Além disso, dados foram obtidos a partir da análise de relatórios, cartas, correspondência eletrônica, ajuda-memórias (aidememoires) e atas de reuniões encontrados em arquivos de ONGs interessadas no projeto Planafloro e de agências executoras do projeto, bem como de notícias na mídia nacional e estrangeira e de artigos acadêmicos sobre a experiência brasileira com o Painel de Inspeção.

\section{A Investigação do Planafloro: Busca de Renovação em um Conflitto Antigo}

\section{O Planafloro e o Dilema entre Desenvolvimento e Proteção Ambiental}

Desde o seu início, o projeto Planafloro foi mais um instrumento usado para endossar agendas políticas específicas das instituições nele envolvidas do que para promover o manejo sustentável dos recursos 
naturais de Rondônia. Para as elites políticas rondonienses, o projeto representava uma fonte adicional de recursos externos, em um momento em que repasses federais e receitas fiscais eram praticamente inexistentes devido à crise econômica do início dos anos 90. No plano nacional, a formalização do empréstimo do Banco Mundial para o Planafloro praticamente coincidiu com a Conferência das Nações Unidas para o Meio Ambiente e Desenvolvimento, realizada no Rio de Janeiro em junho de 1992 (a ECO-92). Ambos os eventos faziam parte da estratégia do então presidente da República Fernando Collor de Mello para projetar internacionalmente o Brasil como um país comprometido com a questão ambiental ${ }^{5}$. Finalmente, para o Banco Mundial, o Planafloro representava não apenas mais um empréstimo ao Brasil ${ }^{6}$, mas também uma oportunidade de melhorar a imagem do Banco e associá-la a iniciativas de proteção ambiental.

As negociações para o financiamento do projeto Planafloro começaram em 1987. Cinco anos transcorreram entre o início das negociações e a aprovação do empréstimo pelo Conselho Executivo do Banco Mundial em março de 1992. Este atraso se explica, em parte, pelo fato de os formuladores do projeto terem de responder às críticas do movimento ambientalista internacional. Uma coalizão de ONGs ambientalistas lideradas pelo Environmental Defense Fund (EDF), baseado em Washington, D.C., com ativistas brasileiros e organizações da sociedade civil (institutos de pesquisa, associações profissionais e grupos de base) exerceu forte pressão sobre o Banco Mundial visando alterações no Planafloro. As ONGs ressaltavam a importância de serem incluídas no projeto precondições de cunho ambiental, as quais deveriam ser executadas em Rondônia antes da liberação de qualquer recurso para o Planafloro. A coalizão ambiental também exigia que fossem criados mecanismos de participação da sociedade civil nos processos de tomada de decisão, execução e monitoramento do projeto. 
Redes Transnacionais de Advocacia Pública: O Projeto Planafloro...

Ao menos em termos da concepção do Planafloro, os esforços dos ambientalistas foram recompensados. O Acordo de Empréstimo do Planafloro determinou que uma série de medidas de proteção ambiental deveria ser executada pelo governo de Rondônia antes da liberação dos recursos ao governo do estado. Entre estas constava, por exemplo, que o governo de Rondônia deveria limitar o desmatamento e proteger áreas indígenas, unidades de conservação e reservas extrativistas. Tais iniciativas deveriam ser realizadas de acordo com as determinações estabelecidas por um plano de zoneamento socioeconômico e ambiental, um dos elementos essenciais do componente ambiental do projeto Planafloro ${ }^{7}$. O Acordo de Empréstimo também exigiu a criação de uma instância de tomada de decisão de composição paritária, isto é, um Conselho Deliberativo formado por um número equivalente de representantes de agências do governo e das organizações da sociedade civil rondoniense.

Oficialmente, o projeto Planafloro começou a ser executado em 1993. No entanto, quando eu estive na região pela primeira vez, em novembro de 1994, a falta de resultados estava gerando uma grande frustração entre vários representantes de organizações da sociedade civil local. Uma das pessoas entrevistadas comentou que ela jamais "imaginou chegar a dezembro de 1994 sem que uma só reserva extrativista tivesse sido criada!" Um outro ativista explicou que "de um ponto de vista legal, o Estado de Rondônia estava inadimplente com relação ao contrato de empréstimo com o Banco já que nenhuma das precondições ambientais havia sido executada". Até mesmo representantes do governo local reconheciam que o "Planafloro não estava andando", em virtude, principalmente, da resistência do Instituto Nacional para Colonização e Reforma Agrária (INCRA) a transferir terras federais para o Estado de Rondônia. Sem essa transferência, o estado não podia legalmente estabelecer unidades de conservação, já que não detinha o controle das terras públicas. Estes e outros problemas na execução do projeto foram detalhados em um relatório inde- 
pendente de monitoramento (COMAI, s/d), o qual, segundo um de seus autores, permaneceu ignorado tanto pelo Banco Mundial quanto pelo governo de Rondônia.

O leitor não deverá se surpreender, portanto, ao saber que, já em 1992/93, algumas organizações de advocacia pública começaram a empreender esforços no sentido de levar os problemas do projeto Planafloro ao conhecimento dos membros do Painel de Inspeção. A primeira destas tentativas foi liderada pelo Grupo de Trabalho de ONGs sobre o Banco Mundial ${ }^{8}$, o qual, no início dos anos 90, estava sob a coordenação de um conhecido ativista brasileiro na área de direitos humanos e ambientais. Ele explica que "no mesmo instante em que o Painel foi criado, este já começou a gerar preocupações no âmbito do Grupo de Trabalho, primeiramente quanto ao seu grau de independência (com relação ao Banco Mundial) e, em segundo lugar, quanto à sua transparência.” Na percepção do GT e de seus membros e aliados internacionais, o projeto Planafloro oferecia a oportunidade ideal pra testar o Painel de Inspeção com relação a esses atributos. Em primeiro lugar, o Planafloro possuía alta visibilidade política, herdada de seu predecessor, o projeto Polonoroeste. Em segundo, o projeto era essencialmente uma iniciativa de cunho ambientalista, tendo sido elaborado de acordo com as diretrizes ambientais definidas em políticas internas do próprio Banco. Por esse motivo, as violações alegadas com relação ao Planafloro inseriam-se diretamente no âmbito de competência do Painel. Em terceiro, a negligência dos órgãos executores do projeto quanto ao cumprimento das precondições ambientais justificava uma investigação do papel do Banco Mundial nesse processo, ainda que o Planafloro propriamente dito se encontrasse nos estágios iniciais de sua execução. Finalmente, o acesso a grupos em Rondônia que representavam as populações beneficiárias do projeto, e que obviamente deveriam ser consultadas com relação a quaisquer iniciativas de advocacia transnacional, poderia ser garantido pelos contatos do diretor executivo do GT. A despeito de todas es- 
Redes Transnacionais de Advocacia Pública: O Projeto Planafloro...

sas vantagens, essa primeira tentativa de levar os problemas do Planafloro à consideração do Painel de Inspeção foi abortada em seus estágios iniciais.

A iniciativa do GT é representativa de um fenômeno que caracterizou a rede transnacional de advocacia mobilizada em torno do Planafloro desde o seu início. Em conseqüência da sua diversidade, os membros dessa rede possuíam agendas e prioridades extremamente diferentes, a despeito de estarem unidos por uma preocupação comum com a sustentabilidade ambiental da região. Em certos momentos, essas agendas diversas coincidiam ou se reforçavam umas às outras dentro de contextos específicos gerados por estratégias de interesse comum. Este foi o caso do pedido de investigação do Planafloro pelo Painel de Inspeção apresentado em 1995. Em 1992/93, porém, a despeito da oportunidade fomentada pelo GT, as organizações da sociedade civil rondoniense não possuíam nenhum interesse em questionar o Planafloro em um nível tão estrutural.

\section{Clivagens Locais}

Estudiosos das dinâmicas política e ambiental em Rondônia explicam essa falta de interesse das organizações locais em questionar a execução do Planafloro de duas maneiras: uma delas ressalta a ingenuidade política tanto dos grupos locais quanto das ONGs estrangeiras que não foram capazes de compreender a natureza do jogo político dominante em Rondônia. Na verdade, as organizações da sociedade civil acreditaram que a sua mera participação em instituições formais de tomada de decisão no Planafloro (tais como o Conselho Deliberativo) garantiria uma influência efetiva na execução do projeto. Os ativistas, portanto, teriam sido incapazes de avaliar adequadamente a força da "política de bastidores" que predominava - e predomina - em Rondônia (Keck, 1998:182) ${ }^{9}$. A outra explicação destaca que organizações da sociedade civil rondoniense não possuíam, no início dos anos 90, capacidade para empreender uma estratégia 
transnacional com implicações técnicas e políticas no grau exigido por um pedido de investigação ao Painel ${ }^{10}$. Segundo um funcionário do GT, essa falta de capacidade tinha a ver, entre outras coisas, com o parco número de funcionários de organizações da sociedade civil rondoniense que possuíam conhecimento técnico e institucional para lidar com as exigências burocráticas relacionadas ao Painel de Inspeção, e ainda poucos eram os que conheciam em profundidade os regulamentos internos do Banco Mundial ou eram fluentes em inglês, condição necessária para se empreender estudos de termos legais e condições processuais relacionados à eventual formulação de um pedido de investigação ${ }^{11}$.

Proponho uma explicação alternativa às expostas acima para a resistência das organizações rondonienses a questionar o projeto Planafloro naquele momento. Meu argumento é que tal resistência esteve mais relacionada com o pragmatismo político dos grupos locais do que com a falta de maturidade política ou técnica dos mesmos. No início dos 90, tais grupos ainda viam o projeto Planafloro como uma oportunidade de criar um espaço político e de pressão da sociedade civil sobre os órgãos responsáveis pela formulação de políticas ambientais e de desenvolvimento para o Estado de Rondônia. Um ano antes de o projeto Planafloro ser aprovado, ONGs rondonienses e grupos de base locais haviam formado o Fórum de ONGs e Movimentos Sociais que atuam em Rondônia, ou Fórum de Rondônia, o qual recebeu apoio de organizações nacionais de advocacia pública, como o já extinto Instituto de Estudos da Amazônia e Meio Ambiente e o Conselho Nacional dos Seringueiros, e de grupos internacionais, como o Oxfam, o World Wildlife Fund for Nature e o Environmental Defense Fund.

O Fórum de Rondônia constituiu-se com o mandato de monitorar políticas públicas em Rondônia, mais especificamente o projeto Planafloro. O Fórum, bem como algumas de suas organizações filiadas p. ex., a Organização dos Seringueiros de Rondônia (OSR), a Orga- 
Redes Transnacionais de Advocacia Pública: O Projeto Planafloro...

nização do Povo Indígena Karitiana e a Federação de Trabalhadores Agrícolas de Rondônia (FETAGRO) -, possuía representantes nas instituições de tomada de decisão e de alocação de recursos do Planafloro. A despeito de estarem perfeitamente conscientes dos obstáculos políticos e burocráticos à sua participação, eles consideravam sua presença formal nas instâncias decisórias do projeto como uma conquista política $^{12}$. Teria sido inconsistente para essas organizações levantar críticas estruturais ao mesmo estando formalmente comprometidas com a sua execução.

É impossível descrever, em poucas páginas, o contexto e os detalhes dos vários esforços empreendidos entre 1992 e 1994, em arenas domésticas e internacionais, pelo Fórum de Rondônia e por seus parceiros no sentido de manter o Planafloro fiel aos seus objetivos ambientais (ver Keck, 1998; Keck e Sikkink, 1998; Millikan, 1998; 2001; Rodrigues, 2000). Internacionalmente, os membros da rede transnacional de advocacia que monitorava o Planafloro, sob a liderança do Fórum de Rondônia, pressionaram o Banco Mundial para que este levasse mais a sério seu papel no acompanhamento do projeto. As ONGs envolvidas coletaram informações sobre omissões na execução do Planafloro e sobre procedimentos irregulares relacionados ao mesmo, e documentaram tais acusações em extensos relatórios independentes (COMAI, s/d). Ativistas também denunciaram problemas na execução do Planafloro em cartas dirigidas à equipe do Banco Mundial responsável pelo projeto e a funcionários de alto escalão naquela instituição ${ }^{13}$.

No âmbito local, representantes do Fórum e de organizações a ele filiadas discutiram exaustivamente questões estratégicas do Planafloro entre si, com membros das equipes de monitoramento do Banco e com representantes governamentais, tentando encontrar maneiras de melhorar o desempenho do projeto em questões ambientais. Muitas ajuda-memórias emergiram de tais negociações, mas a tendência do governo de Rondônia era ignorar tais compromissos tão logo a mis- 
são do Banco deixava o estado. Ainda na esfera doméstica, membros da rede transnacional investiram energia significativa no esforço de manter o governo de Rondônia e as agências responsáveis pela execução do Planafloro comprometidos com os objetivos ambientais deste. Grupos da sociedade civil rondoniense continuaram a participar das instâncias decisórias do projeto e até mesmo de missões para expulsar invasores de áreas protegidas. Esses procedimentos tiveram como resultado mínimo viabilizar o acesso da sociedade civil a informações sobre o projeto.

Aos poucos, no entanto, tornou-se evidente que as redes de patronagem no estado, e não o Conselho Deliberativo, eram a arena principal de tomada de decisões com relação ao Planafloro ${ }^{14}$. Por intermédio de cartas e reuniões, organizações rondonienses passaram a informar funcionários de agências federais ligadas à execução do Planafloro sobre os problemas com o projeto, requerendo deles ação imediata ${ }^{15}$. A estratégia mais eficaz empreendida durante esse período foi a proposição de uma ação civil pública contra o INCRA. Em 1993, o Fórum de Rondônia acusou judicialmente essa agência de violar a lei de zoneamento do Estado de Rondônia. A Justiça deu ganho de causa ao Fórum e o INCRA recebeu notificação para interromper todos os planos referentes ao estabelecimento de projetos de assentamento em áreas designadas exclusivamente como de conservação, ou limitadas a atividades extrativistas.

Para um observador desavisado, as ações descritas acima poderiam parecer um conjunto coerente de iniciativas empreendidas por uma coalizão de ativistas com ideais e agendas comuns. Vistas "de dentro", no entanto, elas parecem mais um mosaico ou uma pintura impressionista. A despeito dos esforços de coordenação do Fórum de Rondônia, o fato de que seus aliados e organizações filiadas possuíam agendas individuais e nem sempre complementares (em alguns casos eram até contraditórias entre si), explica em grande parte essa multiplicidade de estratégias que careciam de uma estrutura organi- 
Redes Transnacionais de Advocacia Pública: O Projeto Planafloro...

zacional comum. Por exemplo, no início da execução do Planafloro, a OSR e o Conselho Missionário Indígena - um grupo de advocacia para direitos indígenas ligado à Igreja Católica - eram favoráveis à manutenção de negociações com o governo sobre o Planafloro, preferindo evitar confrontos políticos diretos. Essencialmente, os representantes das populações indígenas e seringueiras viam no Planafloro uma chance única de garantir recursos para a demarcação de áreas indígenas e reservas extrativistas. Para esses grupos, o Banco Mundial, a despeito de seus vínculos estruturais com um modelo de desenvolvimento problemático, era essencialmente um aliado estratégico $^{16}$.

Organizações representando populações sem-terra e pequenos agricultores rurais (p. ex., o Movimento dos Trabalhadores Rurais Sem Terra (MST) e a FETAGRO) eram ambíguas com relação ao Planafloro e à ênfase deste sobre questões ambientais. Por um lado, as lideranças do MST e da FETAGRO eram sensíveis aos objetivos ambientais do Planafloro; por outro, elas enfrentavam dificuldades para obter o apoio de suas bases para estratégias políticas e jurídicas que impusessem restrições a projetos de assentamento e à expansão da fronteira agrícola em Rondônia (precisamente o objetivo da ação civil pública iniciada pelo Fórum de Rondônia contra o INCRA).

Em vista do descrito acima, era inevitável que a rede transnacional de advocacia mobilizada em torno do Planafloro viesse a sofrer as consequiências das clivagens internas que dividiam seus membros. Diferenças com relação a objetivos e à escolha de estratégias contrapunham diversos grupos locais, impunham pressões sobre as lideranças de certos movimentos sociais, distanciando-as de suas bases, e separavam vários movimentos "de base" dos setores mais "internacionalizados" da rede, tais como a liderança do Fórum, os grupos nacionais de advocacia e, naturalmente, as ONGs internacionais que apoiavam o Fórum. No início dos anos 90, o principal foco de diferenças entre os membros da rede transnacional mobilizada em torno do Pla- 
nafloro estava relacionado à definição dos objetivos do esforço ativista. Para os grupos internacionais e organizações nacionais mais próximos dos primeiros, a mobilização em torno do Planafloro estava associada à Campanha contra os Bancos de Desenvolvimento Multilaterais, conhecida como Campanha $\mathrm{MDB}^{17}$. Em última análise, um dos objetivos da Campanha era questionar o impacto ambiental de políticas de desenvolvimento - no caso específico do Brasil, o efeito das políticas federais e regionais sobre o desenvolvimento da região amazônica. Nesse contexto, as estratégias mais eficazes a serem empreendidas deveriam privilegiar a pressão contra os governos federal e de Rondônia e o Banco Mundial, e até mesmo o confronto com eles, em detrimento de esforços de diálogo e negociação (preferidos, até certo ponto, por grupos locais).

A diversidade de agendas e expectativas no interior da rede transnacional de advocacia mobilizada em torno do Planafloro é bem ilustrada nos parágrafos abaixo. Eles contam a história das tensões geradas no interior da rede pela ação civil pública contra o INCRA e pela crise de legitimidade que se abateu sobre membros da rede em 1994, em parte como conseqüência da opção por mover a ação e das conseqüências que se seguiram a ela. Tal crise foi caracterizada por um período de tensões exacerbadas entre membros da rede em todos os seus níveis, o que levou ao enfraquecimento temporário dos esforços de advocacia.

\section{A Crise de Legitimidade da Rede Transnacional}

A bem documentada e fundamentada ação civil contra o INCRA teve como conseqüência convencer a Justiça rondoniense dos argumentos do Fórum. A Justiça reconheceu que a agência de colonização não apenas negligenciara suas obrigações com relação à condução de estudos de impacto ambiental referentes a seus projetos de assentamento em Rondônia, mas também desrespeitara a Lei de Zoneamen- 
Redes Transnacionais de Advocacia Pública: O Projeto Planafloro...

to do estado. O advogado do Fórum na época explicou que: "Campo Novo [um dos locais onde o INCRA planejava estabelecer um projeto de assentamento] está dentro da Zona 4. O INCRA desapropriou uma área enorme, cerca de $400 \mathrm{~km}^{2}$, para o assentamento de grupos sem-terra. Mas isso está acontecendo em uma área designada [pela Lei de Zoneamento] para reservas extrativistas." 18 Em resposta às denúncias do Fórum, a Justiça rondoniense concedeu medida provisória ordenando que o INCRA suspendesse qualquer iniciativa de colonização em Rondônia.

Em junho de 1994, estimulada pelo resultado favorável obtido pela ação civil, a liderança do Fórum de Rondônia enviou carta ao Banco Mundial em que exigia a interrupção imediata de desembolsos ao Planafloro com base na total incapacidade deste de cumprir suas promessas de proteção ambiental ${ }^{19}$. O pedido do Fórum de suspensão dos recursos para o projeto (implicando a sua efetiva interrupção) recebeu apoio de grupos internacionais de advocacia ambiental e de direitos humanos, de organizações da sociedade civil brasileira e de setores da mídia doméstica e internacional sensíveis às questões ambientais.

Em resposta à carta do Fórum, o Banco Mundial enviou a Rondônia uma missão, em agosto de 1994, cujo mandato incluía aceitar o pedido de interrupção do Planafloro ${ }^{20}$. De acordo com um ambientalista de Washington, que acompanhou o processo de perto, o Banco "estava fora de si com a perspectiva iminente de ter que suspender o Planafloro e, por decorrência, ter que enfrentar mais um escândalo gigantesco em Rondônia". (A referência aqui é aos problemas diplomáticos criados entre o Banco Mundial e o Brasil em conseqüência da degradação ambiental gerada pelo projeto Polonoroeste nos anos 80.) Inesperadamente, no entanto, quando a missão do Banco chegou a Rondônia, ela encontrou um cenário inteiramente diverso daquele que antecipara. As organizações da sociedade civil rondoniense haviam substituído o tom de confronto que caracterizara a car- 
ta-denúncia por uma disposição pragmática de negociar aspectos relativos à continuação do projeto.

O que aconteceu entre os meses de junho e agosto de 1994 em Rondônia? A resposta a esta pergunta só pode ser encontrada se levarmos em conta a diversidade de agendas e expectativas entre os membros da rede de advocacia mobilizada em torno do Planafloro. O pedido de suspensão do projeto fora uma estratégia ousada, porém precipitada, da parte da liderança do Fórum, e atendia, primordialmente, às expectativas políticas e ambientalistas de um subgrupo da rede transnacional, especificamente, a liderança do Fórum de Rondônia e alguns dos seus parceiros nacionais e internacionais. Levada às últimas consequiências, tal estratégia poderia ter se transformado em uma vitória simbólica importante na luta contra a falta de sustentabilidade ambiental das políticas de desenvolvimento do Brasil e do Banco Mundial. Todavia, para as lideranças das organizações de base representando as populações beneficiárias do Planafloro, a prioridade era responder às demandas de seus membros constituintes. A despeito das falhas na execução do Planafloro, o projeto continuava representando a única oportunidade disponível para que essas populações obtivessem algum benefício concreto, tais como maiores recursos para o crédito rural e a demarcação de reservas extrativistas. Um funcionário da OSR, por exemplo, foi enfático quando declarou que "em momento algum, falando pela OSR, nós fomos favoráveis à suspensão do Planafloro. Nós éramos favoráveis a ajustes no programa, mas não podíamos jogar tudo fora. Para nós, teria sido uma perda enorme.” A mesma lógica pode ser inferida de um comentário feito por um ativista próximo aos trabalhadores rurais, que explica: "enquanto houver o dinheiro do Planafloro, haverá recursos para pequenos agricultores. Quando o Planafloro acabar, estes recursos deixarão de existir." 21

Tendo em vista o exposto, fica claro que a liderança do Fórum de Rondônia não possuía o apoio político e o consenso institucional necessá- 
Redes Transnacionais de Advocacia Pública: O Projeto Planafloro...

rios para continuar pressionando pela interrupção do Planafloro. A única alternativa viável para o Fórum era buscar uma reaproximação com suas filiadas e também com suas bases através da adoção de uma postura conciliatória em relação ao Banco Mundial e ao governo do estado. Em agosto de 1994, portanto, o Fórum liderou as negociações com ambos, visando, uma vez mais, encontrar soluções para os problemas de execução dos componentes ambientais do Planafloro.

Em pouco tempo, porém, essa decisão provou ser um "erro estratégico",22, que acabou por levar o Fórum a enfrentar uma crise de legitimidade da qual só viria a se recuperar em 1995, quando do processo de preparação do pedido de investigação do Planafloro pelo Painel de Inspeção. No período que se seguiu às negociações de agosto de 1994, o Fórum e suas organizações filiadas enfrentaram uma série de desafios. Em primeiro lugar, essas organizações tiveram dificuldades em alcançar um ponto de equilíbrio entre suas funções de participantes na execução do Planafloro e de monitores independentes do projeto; além disso, não tiveram facilidades para levar adiante tarefas relacionadas à implementação do mesmo, cuja responsabilidade haviam tomado a si durante as negociações de agosto de 1994; em pouco tempo, ficou evidente que muitos dos compromissos assumidos estavam além da capacidade técnica das organizações responsáveis ${ }^{23}$. Finalmente, os grupos locais precisavam recuperar a confiança de seus aliados nacionais e internacionais - estes últimos haviam apoiado o Fórum na ocasião do pedido de suspensão do Planafloro em junho de 1994, tendo ficado negativamente surpreendidos quando tal estratégia foi abandonada alguns meses depois.

Esses óbices, juntamente com níveis de frustração cada vez maiores em consequiência da falta de resultados do Planafloro, acabaram por gerar no Fórum e na rede transnacional como um todo, uma crise de legitimidade sem precedentes (ver Quadro 1). Em dezembro de 1994, as organizações da sociedade civil rondoniense, finalmente, tiveram que reavaliar sua posição com relação ao projeto, processo de- 


\title{
finido pelo então secretário executivo do Fórum como o "fim da fase romântica" na história da organização.
}

\section{Quadro 1}

\author{
A Crise de Legitimidade do Fórum de Rondônia
}

"O Fórum denunciou o problema [dos projetos de colonização do INCRA] ao Banco Mundial. O Banco veio com poderes para parar tudo. Nós negociamos durante dez dias e a missão do Banco foi embora. O resultado foi uma ajuda-memória que não levou a lugar nenhum! Agora [dezembro de 1994], uma outra missão deve estar chegando, haverá uma outra ajuda-memória [...]. Mas desta vez, não! Porque nós vamos romper com o projeto. Nós [do Fórum] não vamos mais dar legitimidade a essa brincadeira! O Banco Mundial vende o projeto como tendo o apoio das ONGs, da sociedade civil, mas isso não é verdade. A carta ao Banco [exigindo a interrupção do projeto] foi o primeiro passo. Agora, quando a próxima missão do Banco chegar, nós vamos romper. Por que continuar a apoiar o projeto?" (Paulo, funcionário do Fórum de Rondônia, Rondônia, novembro de 1994.)

"As ONGs de Rondônia, hoje, estão passando por uma crise de identidade, uma enorme crise operacional, o Fórum está em um estado lamentável. É uma crise essencialmente interna. Ele pode estar conseguindo manter uma imagem externa, mas internamente é um desastre!" (Miguel, consultor do PNUD, Rondônia, novembro de 1994.)

"Nós chegamos a dezembro de 1994 sem que uma única reserva extrativista ou área indígena tenha sido demarcada! Nós gastamos uma quantidade imensa de energia, dinheiro, muito mesmo, e no entanto o movimento não conseguiu nada! Pior ainda, perdeu credibilidade, está esvaziado atualmente [...]" (Sônia, funcionária da ONG rondoniense INDIA, Rondônia, novembro de 1994).

"O atraso do Planafloro em criar as reservas extrativistas está levando o movimento seringueiro ao descrédito.” (Silvio, funcionário da OSR, Rondônia, novembro de 1994.)

"O Planafloro prometeu muito aos índios, mas não cumpriu nada! Até agora, o Planafloro serviu apenas como estratégia de marketing. O projeto prometeu colocar quarenta médicos nas áreas indígenas e um grande número de enfermeiras, mas tudo continua como sempre esteve, e os problemas de saúde têm se agravado nas áreas indígenas." (Afonso, líder do povo indígena Karintiana, Rondônia, novembro de 1994.)

\section{O Pedido de Investigação ao Painel de Inspeção}

Quando, em 1995, ONGs internacionais, tais como a Amigos da Terra (Friends of the Earth, FoE) e Oxfam, sugeriram aos grupos rondonienses a estratégia de levar o Planafloro ao conhecimento do Painel de Inspeção, a sugestão caiu em solo fértil ${ }^{24}$. Apesar de a pesquisa prepa- 
Redes Transnacionais de Advocacia Pública:

ratória para o pedido de investigação ter sido financiada, iniciada e, essencialmente, conduzida por funcionários e consultores contratados por ONGs ambientalistas internacionais - FoE, Organização de Cooperação para o Desenvolvimento Internacional, NOVIB da Holanda, e o CIEL -, a decisão de requerer a investigação do Planafloro pelo Painel de Inspeção foi tomada em conjunto por grupos locais e internacionais ${ }^{25}$.

O pedido de investigação do Planafloro pelo Painel de Inspeção, basicamente, denunciava o descaso do Banco para com o monitoramento adequado do projeto. Por exemplo, o Acordo de Empréstimo do Planafloro previa o estabelecimento de um programa de reforma institucional que tornasse as políticas públicas federais e estaduais compatíveis com o zoneamento socioeconômico e ambiental de Rondônia e com os princípios de manejo auto-sustentável dos recursos naturais. Tanto o governo federal quanto o de Rondônia negligenciaram o estabelecimento desse programa ${ }^{26}$. O Banco Mundial, por sua vez, nunca demonstrou preocupação em exigir o cumprimento dessa condição. A incapacidade e a falta de vontade política dos governos estadual e federal para harmonizar as políticas públicas de desenvolvimento com os objetivos do Planafloro prejudicaram os resultados do projeto em pelo menos quatro setores: titulação de terras, criação de unidades de conservação, estabelecimento de medidas de proteção ambiental e apoio a comunidades indígenas ${ }^{27}$. Um aspecto fundamental do pedido de investigação, e o item-chave para se compreender por que essa estratégia se tornou o instrumento catalisador da resolução da crise de legitimidade do Fórum de Rondônia, está relacionado a seu objetivo principal. Em lugar de pretender que uma possível investigação pelo Painel resultasse na interrupção do Planafloro, as organizações da sociedade civil rondoniense esperavam que a investigação viesse a "contribuir para a solução dos atuais problemas na execução do Planafloro."28 
Durante o ano que decorreu entre o pedido de interrupção do Planafloro (junho de 1994) e a apresentação do pedido de investigação do projeto ao Painel de Inspeção (junho de 1995), o Fórum e suas filiadas atingiram um nível de amadurecimento político sem precedentes. Tal processo resultou de uma conjunção de fatores, dentre os quais cabe destacar: o aprofundamento da experiência dos grupos rondonienses em negociar tanto com órgãos governamentais quanto com o Banco Mundial; a construção ou reconstrução de relações de cooperação entre grupos que, até então, não compartilhavam uma visão comum em assuntos ligados ao meio ambiente e ao desenvolvimento; a frustração com as promessas do Planafloro; e a necessidade de confrontar as suas próprias fraquezas institucionais no âmbito do projeto. Todas essas experiências ocorreram paralelamente à tomada de consciência - vivida simultaneamente por todos os grupos que, em Rondônia, haviam abraçado iniciativas de advocacia social e ambiental relacionadas ao Planafloro - de que as promessas de cunho ambiental do projeto Planafloro iriam permanecer "no papel".

A novidade da estratégia de recorrer à intervenção do Painel de Inspeção marcou o início de uma nova fase nas relações entre os membros do Fórum e seus aliados nacionais e internacionais, bem como entre o Fórum e as agências responsáveis pela execução e financiamento do Planafloro. Para a liderança do Fórum, principalmente, o pedido de investigação e a ênfase na necessidade de resolução dos problemas de execução do projeto, em vez de pleitear a sua suspensão, representavam também uma oportunidade política. O pedido de inspeção veio a se tornar o veículo ideal para reiterar o compromisso da liderança do Fórum de respeitar e mediar os interesses das bases das organizações filiadas à entidade ${ }^{29}$.

O nível de coesão política entre as organizações da sociedade civil rondoniense durante o processo do Painel de Inspeção era evidente, tanto para indivíduos diretamente envolvidos quanto para observadores externos. Em Rondônia, um dos líderes da FETAGRO declarou: 
"durante o Painel de Inspeção, nós tínhamos uma posição comum com os demais grupos (ambientalistas, indígenas e seringueiros)." Fora de Rondônia, a situação foi assim resumida por um observador: "o Fórum estava passando por uma crise. O Painel de Inspeção reunificou grupos ativistas dentro e fora de Rondônia." ${ }^{30}$ A coesão política dos grupos locais em torno do pedido de investigação atingiu até mesmo organizações que, no passado recente, haviam repudiado algumas das estratégias do Fórum. O representante dos seringueiros, por exemplo, afirmou: "Eu fui favorável ao pedido de investigação [do Planafloro] pelo Painel de Inspeção desde o começo [...] mesmo que, no final, a conseqüiência fosse a interrupção do projeto [...]". A coesão política entre as organizações da sociedade civil rondoniense, fomentada pelo pedido de investigação do Planafloro pelo Painel de Inspeção, teve implicações significativas não apenas para o próprio projeto, mas para o equilíbrio de forças no estado.

\section{Os Impactos do Pedido de Investigação do Planafloro: Desafios e Oportunidades}

\section{Respostas Institucionais ao Pedido de Investigação}

O pedido de investigação do Planafloro pelo Painel de Inspeção provocou reações de quatro grupos diferentes de atores políticos: do governo federal brasileiro, do governo de Rondônia, do Conselho Executivo do Banco Mundial e da equipe do Banco responsável pelo projeto. Ao analisar as reações de cada um desses atores, pode-se identificar, em níveis diversos, a tensão existente entre forças sensíveis às denúncias do pedido e aquelas que veementemente rejeitavam qualquer mérito deste. As reações imediatas e no longo prazo desses atores dão subsídio ao argumento, apresentado no início deste estudo, sobre a natureza do Painel de Inspeção. Em sua configuração atual, o 
Painel é mais uma arena internacional de confronto político que uma instância neutra de investigação. O caso do Planafloro demonstra que a batalha política que se desenrolou no âmbito do Painel de Inspeção teve implicações em pelo menos dois planos. No internacional, ela levou, de imediato, ao questionamento da credibilidade e eficácia do Painel enquanto mecanismo de prestação de contas das instituições financeiras multilaterais à sociedade civil global. Na realidade, o pedido de investigação do Planafloro deu ensejo a processos internos de redefinição e reavaliação do Painel que, se concretizados, poderão vir a restringir a validade deste enquanto instrumento de prestação de contas. No plano doméstico, o debate gerado pelo pedido de investigação do Planafloro criou oportunidades que, em última instância, contribuíram para aumentar o poder de pressão política das organizações da sociedade civil rondoniense sobre o governo do estado.

O pedido de investigação do Planafloro, entregue ao Painel de Inspeção em 17 de junho de 1995, surpreendeu tanto os governos brasileiro e de Rondônia quanto o Banco Mundial ${ }^{31}$. Isso explica, ao menos em parte, a falta de coerência nas respostas desses atores ao pedido. A primeira delas veio da equipe do Banco Mundial responsável pelo Planafloro, que a submeteu ao Conselho Executivo do Banco - instância responsável por aprovar ou não a investigação de projetos. No documento, a equipe relegava a um plano secundário o mérito das denúncias e requeria que o pedido de investigação fosse julgado improcedente, uma vez que haveria irregularidades técnicas e legais no texto apresentado pelo Fórum de Rondônia e seus aliados, relegando a um plano secundário o mérito das denúncias. Na realidade, a resposta do Banco consistia, essencialmente, em pressupostos contrafactuais: os administradores do Planafloro argumentavam que as populações a serem beneficiadas estariam em piores condições caso o projeto não houvesse sido iniciado. O fundamento legal era que as diretrizes internas do Painel só permitiam a análise dos casos em que os 
demandantes provassem "dano material efetivo" causado pelo Banco. Ora, o Planafloro havia apenas deixado de produzir benefícios potenciais ou planejados às populações-alvo, o que não constituía "dano material efetivo" (Hunter, s/d; Millikan, 2001) ${ }^{32}$. Ao mesmo tempo, porém, que a equipe do Banco rejeitava as denúncias feitas no pedido de investigação do Planafloro, ela intensificava seu monitoramento sobre a execução do projeto. Em pouco tempo, o Banco Mundial abandonou sua postura complacente e passou a pressionar os governos brasileiro e de Rondônia para que estes executassem importantes medidas de proteção ambiental previstas pelo projeto. Essa situação foi avaliada por um observador como esquizofrênica. "Afinal, por que a equipe do Banco estaria empreendendo tantos esforços para solucionar problemas que ela nega existir?" (Millikan, 2001) $)^{33}$.

O pedido de investigação do Planafloro gerou intermináveis negociações políticas e sérias divisões entre os membros do Conselho Executivo do Banco ${ }^{34}$. No final desse processo, o Conselho Executivo optou por aceitar o Plano de Ação proposto pela equipe de administração do Planafloro como um substituto adequado a uma investigação do projeto por parte do Painel. A aceitação do Plano de Ação e a rejeição do pedido de investigação do Planafloro foi a alternativa encontrada pelos diretores executivos do Banco para solucionar o dilema em que se encontravam, e que se tornou evidente durante as reuniões do Conselho Executivo no correr de 1995. David Hunter, ativista ligado à ONG ambientalista CIEL, resumiu-o brilhantemente: "O Conselho confrontou-se com a difícil escolha de aprovar a investigação e causar um embaraço diplomático ao Brasil - um cliente tomador de empréstimo importante do Banco e também membro votante no processo - ou negar a investigação, levando ao enfraquecimento do recém-criado Painel de Inspeção.",35

A falta de consenso no Conselho Executivo com relação ao pedido de investigação do Planafloro estimulou o diretor executivo brasileiro, Marcos Caramuru de Paiva, a obstaculizar a investigação. A preocu- 
pação principal do Brasil era garantir a soberania nacional. O país jamais se sujeitaria a uma investigação interna conduzida por um corpo internacional de especialistas, independentemente da natureza do mandato desses indivíduos. Na verdade, o diretor brasileiro estava seguro, desde o início do processo, de que ele, com o respaldo diplomático do Brasil, seria capaz de evitar a investigação do Planafloro $^{36}$. Esta certeza foi transmitida por Paiva aos representantes das organizações da sociedade civil rondoniense, em outubro de 1995, em uma reunião em Washington durante o encontro anual do Banco Mundial e do Fundo Monetário Internacional. Além do encontro com o diretor executivo brasileiro, líderes do Fórum de Rondônia, do movimento seringueiro e de grupos indígenas no estado estiveram presentes em reuniões com diretores executivos dos Estados Unidos, de países escandinavos e de alguns outros, na esperança de obter o apoio destes à investigação. O lobby das lideranças rondonienses, porém, provou ser inútil. O Conselho Executivo, finalmente, decidiu negar autorização para uma investigação formal do Planafloro ${ }^{37}$.

Assim como ocorreu com a equipe de administração do Planafloro e com o Conselho Executivo do Banco Mundial, a reação do governo de Rondônia ao pedido de investigação também esteve envolta em contradições. Estas devem ser entendidas como consequiência das pressões políticas sobre a administração de Walter Raupp, que havia assumido o governo de Rondônia poucos meses antes de o pedido de investigação ser apresentado ao Painel. As primeiras pressões que Raupp enfrentou vieram da parte do Banco Mundial, através da intensificação do monitoramento sobre o projeto. $\mathrm{O}$ recrudescimento dos esforços de controle do mesmo incluiu o aumento do número de visitas de funcionários do Banco a Rondônia e o envio de funcionários de alto escalão, inclusive de diretores executivos, para discutir com o governo a execução do Planafloro ${ }^{38}$. O segundo tipo de pressão enfrentada pelo governo de Rondônia partiu do governo brasileiro que queria evitar, a todo custo, o escrutínio internacional sobre po- 
Redes Transnacionais de Advocacia Pública: O Projeto Planafloro...

líticas e práticas ambientais em Rondônia - nesse caso, o total cancelamento do Planafloro era preferível a uma investigação do projeto por um órgão internacional. A administração Raupp levou a sério as pressões do governo federal, já que o cancelamento do Planafloro levaria à paralisação total de novas linhas de crédito para o estado ${ }^{39}$. O terceiro conjunto de pressões partiu de grupos de base co-signatários do pedido de investigação, tais como o MST e a FETAGRO. Ambos tinham fortes vínculos políticos com o Partido dos Trabalhadores, que havia se tornado parte da coalizão governante a partir de seu apoio à candidatura Raupp no segundo turno das eleições para o governo do estado. Finalmente, o governo Raupp continuava comprometido com suas tradicionais bases de apoio, as elites políticas e econômicas do Estado de Rondônia.

Tendo em vista o contexto político acima descrito, as medidas adotadas pelos governos federal e de Rondônia imediatamente após a apresentação do pedido de investigação do Planafloro não surpreendem. Em 28 de julho de 1995, as agências federal e estadual responsáveis por questões agrárias (INCRA e INTERON) assinaram um acordo pelo qual o controle das terras públicas federais passava para o estado. Tal pacto havia sido uma precondição do Planafloro e um passo essencial para viabilizar a criação de unidades de conservação e reservas extrativistas em Rondônia. No correr do mês que se seguiu a esse acordo, o governo de Rondônia criou quinze reservas extrativistas. No final de 1995, o processo de demarcação da maioria das áreas indígenas no estado havia sido completado. Durante o ano seguinte, um "progresso notável" foi observado com respeito ao manejo das unidades de conservação e ao estabelecimento de infraestrutura social e econômica nas reservas extrativistas (Smeraldi e Millikan, 1997).

A maioria das análises sobre as conseqüências do pedido de investigação do Planafloro identifica uma clara relação de causalidade entre este, as subseqüentes pressões exercidas pelo Banco Mundial sobre 
os governos brasileiro e de Rondônia e a adoção de medidas vitais para a melhoria do desempenho ambiental do Planafloro (Keck, 1998; Millikan, 2001; Hunter, s/d). No entanto, algumas pessoas diretamente ligadas aos eventos mencionados preferem ressaltar a contribuição de estratégias anteriores ao pedido de investigação. Nesse sentido, o fato de que importantes medidas de proteção ambiental previstas pelo Planafloro foram executadas imediatamente após a apresentação do pedido de investigação sugere que estas estavam sendo seriamente consideradas pelas agências executoras mesmo antes de o projeto ser levado ao Painel de Inspeção. O pedido, portanto, apenas acelerou uma decisão que se tornara inevitável tendo em vista as pressões exercidas, primeiramente, pela rede transnacional de advocacia, e, em segundo lugar, pelo Banco, cada vez mais insatisfeito com os rumos do projeto ${ }^{40}$.

A execução de importantes medidas de proteção ambiental pelo governo de Rondônia tornou-se inevitável dado o pedido de investigação. No entanto, isso não eliminou a determinação do governo do estado de encontrar formas de neutralizar os efeitos de tais medidas e, assim, "pacificar" sua tradicional clientela, as elites econômicas do estado, em particular os interesses madeireiros. No correr de 1996, o governo Raupp emitiu uma série de ordenamentos legais que visavam, diretamente, reverter as conquistas ambientais do Planafloro. As organizações da sociedade civil rondoniense, porém, foram capazes de fazer frente à maioria deles, o que indica o aumento de sua capacidade política em decorrência do pedido de investigação. Alguns exemplos importantes desse confronto político entre estado e sociedade civil merecem ser citados. Em fevereiro de 1996, Raupp assinou o Decreto $n^{\circ} 7.341$, que permitia a exploração madeireira em áreas designadas pela Lei de Zoneamento de Rondônia como exclusivas à atividade extrativista. No entanto, em menos de trinta dias, o governo foi forçado a cancelar tal medida por ser parte vencida na ação civil pública movida pelo Fórum de Rondônia contra o decreto. Em ju- 
Redes Transnacionais de Advocacia Pública: O Projeto Planafloro...

nho de 1996, o governador aprovou a Lei nº 152, regulamentando a continuação do processo de zoneamento. Esta, porém, continha sérias irregularidades, que foram denunciadas ao Banco Mundial pelas organizações rondonienses. Graças a tais queixas, os advogados do Banco puderam intervir no sentido de corrigir tais irregularidades. Antes que 1996 terminasse, Raupp elaborou mais um decreto que implicava riscos potenciais ao meio ambiente. O Decreto $\mathrm{n}^{\circ} 7.634$ incluía a Federação das Indústrias de Rondônia (FIERO) entre os membros de um comitê paritário responsável por iniciativas que visavam prevenir a invasão de unidades de conservação e a exploração de seus recursos naturais. Grupos da sociedade civil rondoniense opuseram-se ao decreto alegando que a participação da FIERO no comitê incorria em conflito de interesses, dado os notórios vínculos da Federação com a indústria madeireira no estado. A FIERO foi obrigada a abandonar o comitê e novos assentos foram criados para permitir a participação de representantes dos grupos seringueiros e dos povos indígenas. Finalmente, membros da coalizão governamental enviaram à Assembléia Legislativa do Estado projetos de lei que reduziam as áreas de dois parques estaduais e uma reserva extrativista. Tais projetos encontram-se ainda em fase de tramitação. De todo modo, eles estabelecem um precedente para esforços futuros de redução dos limites das unidades de conservação estabelecidas pelo Planafloro.

\section{- Pedido de Investigação e a Capacitação Política da Sociedade Civil Rondoniense}

O aumento das tensões entre as organizações rondonienses e o governo do estado reforçou a decisão da equipe de administração do Planafloro do Banco Mundial de facilitar ou mediar o diálogo entre as partes $^{41}$. O Banco procurou alcançar esse objetivo a partir de várias iniciativas, dentre elas a promoção de uma oficina sobre a participação da sociedade civil na condução do Planafloro, em março de 1996; a 
realização de uma avaliação independente do projeto, completada em maio de 1996; culminando com a execução do Seminário de Avaliação do Planafloro, em junho de 1996. Um funcionário do Banco considera que tais iniciativas foram uma conseqüência direta do pedido de investigação do Planafloro pelo Painel de Inspeção e da

“[...] competência que as organizações da sociedade civil rondoniense haviam demonstrado em seu questionamento do modo como o Planafloro estava sendo executado [...]. A partir do pedido de investigação, o Banco Mundial mudou a sua percepção sobre o Planafloro. O Banco percebeu que precisava mudar de estratégia [...]. Para se chegar a uma situação positiva [win-win situation] era preciso haver colaboração [entre governo e sociedade civil]., ${ }^{, 2}$

A oficina sobre participação das organizações rondonienses no Planafloro serviu como um fórum inicial onde os grupos da sociedade civil criticaram abertamente o Banco e apresentaram queixas com relação às dificuldades de participação no projeto. O mesmo funcionário do Banco explica: "isso foi extremamente válido já que quando chegamos ao Seminário de Avaliação esses assuntos já haviam ficado para trás." Uma vez que a atmosfera de confronto entre o Banco Mundial, o governo de Rondônia e grupos da sociedade civil local fora atenuada no decorrer de iniciativas anteriores, o Seminário de Avaliação do Planafloro transformou-se em uma oportunidade para um diálogo produtivo sobre os aspectos técnicos da execução do projeto. As organizações da sociedade civil assumiram o controle desse processo por dois motivos: em primeiro lugar, o documento de trabalho que norteou as discussões durante o Seminário consistia no relatório final da avaliação independente. (Esta avaliação havia reiterado a maioria das acusações que tinham sido levadas ao Painel de Inspeção, legitimando assim a posição das organizações da sociedade civil.) Em segundo lugar, a falta de preparo do governo de Rondônia ficou evidente logo no início do Seminário. Um funcionário do Banco reconstituiu a situação da seguinte forma:

"O Fórum estava bem preparado. As ONGs tinham propostas melhores, mais bem formuladas, e mais bem detalhadas, do que o governo. Nós assis- 


\section{Redes Transnacionais de Advocacia Pública:}

O Projeto Planafloro...

timos a discursos bem formulados, feitos por representantes de vários setores da sociedade civil. Quando chegou a vez do governo, o Secretário de Planejamento não disse absolutamente nada. O governo carecia de capacidade para fazer uma defesa coerente do programa face às críticas das ONGs. O governo, então, decidiu negociar. ${ }^{, 4}$

O pragmatismo político das organizações da sociedade civil rondoniense - um atributo que eu identifiquei no início deste estudo - tornou-se mais uma vez evidente durante as negociações travadas no Seminário de Avaliação. Desde setembro de 1995, isto é, apenas alguns meses após a apresentação do pedido de investigação do Planafloro, os grupos rondonienses já contavam com a rejeição deste pelo Conselho Executivo do Banco Mundial. Era importante, portanto, preparar estratégias alternativas de ação, de modo a fazer o melhor uso possível das vantagens políticas obtidas a partir da pressão gerada pelo pedido. Nesse sentido, os ativistas rondonienses decidiram concentrar seus esforços em uma demanda-chave: exigir que uma parte dos recursos do Planafloro chegasse diretamente aos seus beneficiários ${ }^{44}$. Para que isto se tornasse realidade, as organizações rondonienses sabiam que teriam que negociar com o governo.

Por sugestão do secretário de Planejamento de Rondônia, Emerson Teixeira, o Seminário de Avaliação foi interrompido enquanto governo e sociedade civil negociavam. Funcionários do Banco Mundial serviram de mediadores nas negociações, enquanto os consultores ligados a organizações de advocacia pública nacionais e estrangeiras auxiliavam na preparação das propostas dos grupos rondonienses. Os entendimentos estiveram centrados em duas demandas da sociedade civil: a primeira era de que recursos para o Planafloro fossem canalizados de modo mais direto e eficiente, o que implicava a exclusão de algumas agências governamentais do programa; a segunda demanda era de que uma parte dos recursos fossem remanejados para a expansão de um pequeno subcomponente do Planafloro destinado a financiar iniciativas comunitárias. Esse subcomponente havia sido identificado pela avaliação independente como uma das poucas ini- 
ciativas do Planafloro que estavam sendo bem conduzidas. Ao final dos entendimentos, as organizações da sociedade civil rondoniense tinham alcançado seus objetivos. Diversas agências estatais haviam sido excluídas do projeto e um terço dos recursos ainda disponíveis para o Planafloro (aproximadamente US\$ 20 milhões) foi direcionado para um fundo de financiamento de iniciativas comunitárias denominado Projeto de Apoio a Iniciativas Comunitárias (PAIC). O governo de Rondônia, no entanto, manteve o controle sobre a administração do Planafloro e a responsabilidade pela execução de seus demais componentes, isto é, conservação ambiental e infra-estrutura de transportes.

Em retrospecto, a conquista do PAIC foi, ao mesmo tempo, uma benção e uma maldição para as organizações rondonienses. Uma das principais vantagens dessa conquista foi o aumento da legitimidade que essas organizações e suas lideranças obtiveram junto às suas bases, já que a luta da sociedade civil finalmente se traduzira em potenciais benefícios para as comunidades locais ${ }^{45}$. Uma segunda vantagem foi a intensificação do diálogo entre organizações da sociedade civil e agências do governo, a partir do qual cresceu o respeito destas últimas pela competência das lideranças populares com relação a questões ambientais e sociais em Rondônia e pela capacidade destas de propor modelos de desenvolvimento alternativos. Finalmente, com base em avaliações preliminares do PAIC, considera-se que este pode vir a contribuir para o desenvolvimento sustentável de Rondônia (Browder, 1998).

No entanto, o PAIC tornou-se igualmente uma fonte significativa de problemas. Talvez o maior deles tenha sido o aumento de demandas e expectativas que ele gerou sobre as próprias organizações locais. Desnecessário mencionar que estas nem sempre estiveram preparadas para responder a tais desafios. Um segundo problema refere-se ao fato de que o interesse primordial das organizações locais pelo PAIC implicou um distanciamento entre elas e seus aliados nacionais 
Redes Transnacionais de Advocacia Pública:

e internacionais. Estes últimos, apesar de reconhecerem os méritos do PAIC, consideram seus objetivos muito restritos e regionais, contribuindo pouco para a discussão de questões mais abrangentes, tais como políticas públicas para o desenvolvimento da Amazônia ou a eficácia de mecanismos internacionais nos moldes do Painel de Inspeção. As vantagens e os desafios do PAIC para as organizações rondonienses e para as dinâmicas política e ambiental locais são discutidos em maior detalhe a seguir.

\section{PAIC: Ganhos e Desafios}

A frustração da sociedade civil rondoniense com o PAIC teve início logo que o programa começou a ser executado. Avaliações formais e informais do mesmo, disponíveis até 2001, ressaltam o enorme desafio que o projeto gerou para a limitada capacidade das organizações da sociedade civil rondoniense. Por exemplo, as exigências burocráticas do PAIC para aprovação de verbas eram extremamente complexas. As comunidades locais dependiam de consultores certificados, ou "técnicos," para redigir propostas de financiamento de acordo com os critérios do PAIC. O processo de seleção e treinamento desses técnicos era complicado e moroso, e inúmeras vezes manipulado pelo governo estadual. Vários deles demonstraram ter um baixo nível de comprometimento com as comunidades assistidas, em consequiência, muitas das propostas de financiamento eram reproduzidas de forma idêntica, não possuindo relação alguma com as realidades específicas das comunidades beneficiadas. Um problema associado ao da "indústria de técnicos" foi o estímulo inconseqüente à criação acelerada de associações comunitárias. Um número expressivo delas foi formado em resposta às oportunidades oferecidas pelo PAIC, em vez de serem respostas institucionais ao nível de organização e consenso das suas respectivas comunidades.

Ainda entre os desafios do PAIC se encontra o fato de que os comitês regionais de seleção de projetos, compostos paritariamente por re- 
presentantes do governo e de organizações da sociedade civil, ficaram sobrecarregados devido ao grande número de propostas apresentadas. Estas não apenas necessitavam ser avaliadas, mas tal análise deveria se dar de acordo com procedimentos específicos. Cada proposta, na verdade, impunha uma demanda de tempo significativa sobre os membros do comitê. (Estes e outros problemas são discutidos por pessoas diretamente envolvidas nesse processo no Quadro 2.) A percepção das lideranças rondonienses sobre os entraves na execução do PAIC foi confirmada por uma avaliação formal do programa conduzida por John Browder, em 1998, e financiada pelo Banco Mundial. Browder alerta para a falta de sustentabilidade de muitas das iniciativas financiadas pelo PAIC, resultado atribuído não apenas a falhas na formulação dos projetos ${ }^{46}$, mas também ao baixo nível de legitimidade das associações comunitárias responsáveis pelo manejo dos recursos.

A despeito das dificuldades técnicas de execução, o retrocesso mais sério enfrentado pelo PAIC foi de natureza política. O aniversário do segundo ano da iniciativa coincidiu com um ano eleitoral (1998) e com a campanha para a reeleição do governador Raupp. Em uma manobra desesperada para tentar obter o apoio dos funcionários públicos, cujos salários estavam atrasados, o governador, arbitrariamente, desviou verba do PAIC para o pagamento do funcionalismo estatal ${ }^{47}$. As conseqüências dessa decisão foram desastrosas para as associações comunitárias e ONGs que já haviam assumido diversos compromissos contando com esses recursos. Vários projetos foram paralisados, safras foram perdidas, e fornecedores frustrados com a falta de pagamento iniciaram ações judiciais contra as associações que não conseguiram pagar por produtos que haviam encomendado.

Apesar de todos esses problemas, representantes das organizações locais e alguns de seus aliados fora de Rondônia ainda foram capazes de avaliar o processo do PAIC como uma conquista importante da sociedade civil, tanto em termos políticos quanto ambientais (ver Qua- 
Redes Transnacionais de Advocacia Pública: O Projeto Planafloro...

\author{
Quadro 2: Desafios à Capacidade Técnica das Organizações da \\ Sociedade Civil Rondoniense
}

"[As negociações para o PAIC transcorreram durante todo o ano de 1996] Após este período, a sociedade civil rondoniense teve que se desdobrar para poder oferecer pessoas capacitadas para elaborar manuais, definir linhas prioritárias dos PAICs, quem seriam os beneficiados, e ficou definido que seriam os seringueiros, as populações indígenas, os pequenos agricultores e ribeirinhos [...]. A tentativa foi a de se trabalhar a viabilização, o manual do PAIC, da forma menos complicada possível. Só que há limites. Por exemplo, a associação [beneficiária] tem que existir há pelo menos um ano, a procuradoria do estado não aceitou que se constituíssem associações só com o fim de receber recursos do PAIC. Mas houve exceções para as populações indígenas [...]. Por um lado, essa exceção foi boa, mas, por outro, criou um problema sério para muitas associações indígenas porque, de uma hora para outra, nós tínhamos cerca de 12 associações indígenas até 1994 e em 1996/7 nós passamos a ter 36. Foi um salto muito grande! Muitas das associações não sabiam nem pra que estavam se constituindo. O técnico da FUNAI ficava atrás dizendo 'tem que criar, tem que criar, para poder pegar o dinheiro.' Isso gerou uma expectativa muito grande [...]. A tendência dos projetos indígenas era o social, o econômico, integrado à vivência da comunidade. Por exemplo, tinha projeto de piscicultura, consórcio agroflorestal, para casa de farinha, reforma de escola, reforma do posto de saúde. E esse era o problema. Afinal, essas eram as necessidades deles, mas que não eram atendidas pelo governo. Mas como os governos federal e estadual eram ausentes, os índios acabaram jogando tudo para os PAICs. Isso foi um complicador pois o que parecia ser muita grana, de repente não era, pois não dá pra substituir o governo [...]. Em 1996 a CUNPIR [Coordenação da União dos Povos Indígenas de Rondônia] assumiu, por pressão do Banco Mundial e do governo do estado, a área de saúde indígena no Planafloro. Colocaram a responsabilidade nas mãos das ONGs dizendo: 'alguém tem que assumir porque o governo não pode mais.' A assessoria da CUNPIR na época não conseguiu refletir sobre essa decisão [...]. A CUNPIR acabou sendo a responsável total pela prestação dos serviços de saúde. Mas o projeto relacionado aos recursos para pagar funcionários para trabalhar na saúde foi tão mal elaborado que só dava pra pagar o pessoal no campo. Não sobrava nada para administração, monitoria, etc. Em 1997 a CUNPIR afundou em dívidas e acabou implodindo.” (Júlio, assessor da CUNPIR, maio de 2000, Rondônia)

"[Com o PAIC] acho que de fato houve um avanço muito grande no sentido de se definir e conquistar um espaço político significativo. A sociedade civil, porém, não teve 'perna' para fazer o acompanhamento político necessário a um programa dessa magnitude. Isso é um problema. Algumas pessoas na época disseram que a sociedade civil havia sido cooptada. Acho que não passou por essa questão de cooptação. A cooptação é uma coisa intencional e não foi o caso. O próprio governo resistiu muito à definição do PAIC. O que ocorreu de fato foi isso: muitas entidades se envolveram com a execução do projeto e no final faltou recurso humano para fazer o acompanhamento necessário da iniciativa [...] [muitos problemas ocorreram] porque, de fato, houve uma baixa capacidade da sociedade civil de monitorar tudo isso. Para mim, o estrangulamento foi de recursos humanos mesmo. Não apenas faltaram pessoas com capacidade política, mas também pessoas com conhecimento técnico [...] principalmente nas áreas financeira e orçamentária." (Paco, maio de 2000, Rondônia)

"Não é só uma questão de cooptação. Isso pode até ter acontecido, mas eu acho que em grande medida é uma questão de capacidade dessas entidades de implementar projetos [do PAIC]. Elas não deram conta do que assumiram. Ainda mais com toda essa burocracia pesada, elas não deram conta de fazer outras coisas [com as quais estavam comprometidas]. Muitas entidades e associações não tinham preparo para lidar com isso e se enrolaram na prestação de contas." (Breno, maio de 2000, Brasília) 
dro 3). Na realidade, a despeito dos sérios problemas de execução do PAIC, o próprio consultor John Browder (1998:20) calcula que "aproximadamente 50/60\% dos 146 projetos aprovados até hoje apresentam fortes indicadores de provável sucesso.” Com relação aos objetivos de cunho estritamente ambiental do PAIC, Browder é cautelosamente otimista por duas razões. Em primeiro lugar, apesar de o programa ter priorizado o desenvolvimento comunitário em detrimento da proteção ambiental, PAICs bem-sucedidos deverão ter como efeito colateral estabilizar populações locais. Isso deverá aliviar pressões antrópicas sobre áreas de conservação. É também significativo que pequenos agricultores - que, em termos demográficos, constituem o setor da população que mais ameaça as unidades de conservação - tenham sido os beneficiários de $80 \%$ dos projetos aprovados pelo PAIC entre 1997 e 1998. Em segundo lugar, muitas das atividades classificadas pelo PAIC como "produtivas" ou de "geração de renda" trazem, claramente, "um forte benefício de longo prazo para os objetivos de conservação ambiental.” Alguns exemplos são os projetos de apicultura e piscicultura e os de recuperação de áreas degradadas através do replantio agroflorestal (idem:14).

A questão da contribuição do PAIC para a preservação ambiental de Rondônia é particularmente relevante para que se avalie o impacto do pedido de investigação do Planafloro pelo Painel de Inspeção. Alguns críticos, como, por exemplo, Millikan, apontam três problemas relacionados ao PAIC. Em primeiro lugar, o PAIC sozinho não responde por todas as falhas de execução que foram denunciadas pelo pedido de investigação. Segundo, a reestruturação do Planafloro que deu origem ao PAIC desviou recursos materiais e administrativos do componente ambiental do projeto para outras áreas (inclusive para o PAIC). Terceiro, como as organizações da sociedade civil rondoniense passaram a dedicar todas as suas energias às demandas do PAIC, elas diminuíram a pressão sobre o governo, que ficou livre para negligenciar seus compromissos na área ambiental (Millikan, $1998 ; 2001)^{48}$. 


\title{
Redes Transnacionais de Advocacia Pública: O Projeto Planafloro...
}

\section{Quadro 3}

\section{A Contribuição do PAIC}

\begin{abstract}
"Eu acho que o PAIC, na minha avaliação, foi uma experiência completa e muito positiva, apesar das falhas. Claro que houve projetos mal executados, sem o processo participativo, deu confusão interna nas comunidades [...]. Mas também houve muitos projetos que estão aí em campo que não existiriam sem o PAIC.” (Paco, maio de 2000, Rondônia)

"Os PAICs são, portanto, uma forma de transferir os recursos do estado às organizações que são mais permeáveis à questão ambiental. O projeto tem uma importância no sentido de promover uma gestão mais descentralizada, uma agricultura mais sustentável. No caso dos seringueiros, o PAIC até teve um impacto ambiental mais direto nas reservas. No caso dos índios, ele encorajou atividades alternativas à extração da madeira e à mineração." (Manuel, funcionário da WWF-Brasil, maio de 2000, Brasília)

"A linha de discussão hoje dos seringueiros [OSR], por exemplo, e das comunidades indígenas também, é a de aumentar a produção, mas isto dentro do âmbito do projeto [PAIC]. Mas estas comunidades também querem garantir a [preservação] da área. Para elas é importante recuperar a área que foi devastada por um madeireiro ou pela colonização.” (Júlio, maio de 2000, Rondônia)
\end{abstract}

Neste ponto, as avaliações tornam-se turvas já que os analistas - e eu me incluo neste grupo - não podem beneficiar-se do distanciamento de seu objeto de análise que o passar do tempo proporciona. O Planafloro, assim como o PAIC e o zoneamento socioeconômico e ambiental do estado, são processos ainda em andamento em Rondônia. Eventos recentes, porém, têm ressaltado as contradições inerentes a vários processos deslanchados pelo pedido de investigação. $\mathrm{O}$ impacto positivo do pedido, tanto para o aumento da capacidade política dos grupos da sociedade civil local quanto para a melhoria da execução das medidas ambientais do Planafloro, provocou fortes reações da parte das elites políticas e econômicas no estado comprometidas com uma agenda desenvolvimentista. $\mathrm{O}$ confronto entre as forças comprometidas com um modelo de desenvolvimento tradicional e aquelas que defendem alternativas auto-sustentáveis se intensificou em Rondônia, a partir de 1998, quando uma coalizão de forças conservadoras, lideradas pelo Partido da Frente Liberal (PFL), assumiu o governo do estado.

Até agora, as previsões de Millikan parecem ter se confirmado. Um dos primeiros atos do novo governador José Bianco foi reduzir o con- 
tingente da polícia florestal e redirecionar seus recursos materiais e políticos para a polícia estadual ${ }^{49}$. Recentemente, a liderança dos seringueiros recebeu informação de seus aliados políticos na administração do estado de que o governador pretendia reduzir, em aproximadamente um terço, as áreas das reservas extrativistas de Jaci-Paraná e Rio Preto-Jacundá. A medida teria o apoio de membros da equipe do Banco Mundial para o Planafloro ${ }^{50}$. Não está claro como os seringueiros e seus aliados dentro e fora de Rondônia reagirão a essas ameaças.

A ofensiva do governo de Rondônia contra as medidas de proteção ambiental promovidas pelo Planafloro a partir de pressões da sociedade civil tem produzido (ou acentuado) clivagens entre os distintos grupos. Desde que o dinheiro do PAIC foi desviado por Raupp, o MST e a FETAGRO passaram a defender o fim de qualquer relação das entidades da sociedade civil rondoniense com o Planafloro. Representantes dos seringueiros, das populações indígenas e de pequenas associações de produtores rurais, no entanto, preferiram continuar envolvidos na execução do projeto e manter o diálogo com o governo, particularmente através da mediação do Banco Mundial. Recentemente, o MST e a FETAGRO anunciaram formalmente seu desligamento de quaisquer instâncias de participação do Planafloro, apesar de continuarem determinados a lutar pela adequada execução do projeto.

Essa divisão entre as organizações da sociedade civil tem criado novos desafios para um adequado monitoramento do Planafloro e para o sucesso dos esforços de resistência contra a ofensiva do estado no que se refere ao componente ambiental do projeto. É necessário ressaltar, porém, que o fato de o MST e a FETAGRO não mais participarem do Planafloro não impediu que ambos continuassem, juntamente com o Fórum de Rondônia, a mobilizar esforços no sentido de pressionar o governo a devolver os recursos desviados do PAIC em 1998. Nos últimos anos, essas organizações também participaram de 
Redes Transnacionais de Advocacia Pública: O Projeto Planafloro...

discussões relacionadas à segunda fase do processo de zoneamento. Juntamente com o Fórum de Rondônia e suas filiadas, elas promoveram oficinas de trabalho concernentes ao zoneamento e estiveram presentes em audiências públicas.

Em parte devido às diferenças que continuam a contrapor as organizações da sociedade civil rondoniense, os esforços recentes que estas têm empreendido para monitorar o Planafloro e outras políticas públicas em Rondônia têm características bastante distintas daquelas observadas em estratégias anteriores. A primeira característica é o isolamento das organizações locais. A dificuldade de elaboração de uma agenda comum entre elas tem tornado difícil e mesmo impedido que essas organizações mantenham contato permanente com seus aliados fora de Rondônia. Isso tem sido especialmente problemático tendo em vista o desenrolar do mais recente conflito entre o governo de Rondônia e as forças conservadoras no estado e os setores da sociedade civil comprometidos com a preservação ambiental. Esse confronto diz respeito à aprovação da lei que regulamenta a segunda etapa ("aproximação") do zoneamento socioeconômico e ambiental do estado. Sem entrar nos detalhes dessa disputa, é suficiente mencionar que tal lei cria um precedente perigoso para a política brasileira de conservação florestal $^{51}$.

A segunda característica importante que tem marcado as lutas das organizações rondonienses subseqüentemente ao pedido de investigação do Planafloro é o fato de elas estarem confrontando as elites políticas estaduais diretamente, sem considerar estratégias que envolvam quer o Banco Mundial quer instituições e arenas internacionais. Essa autonomia de ação também se reflete no fato de a maioria das estratégias atuais de mobilização em defesa de direitos sociais e ambientais na esfera do Planafloro estar sob a liderança de organizações de base, tais como a dos seringueiros (OSR) ou a dos trabalhadores rurais (FETAGRO), e não de grupos de apoio ou assessoria. O histórico do ativismo político e ambiental em torno do projeto Plana- 
floro foi crucial para consolidar essa autonomia, como explica um líder da FetAGRo:

"O espaço [da FETAGRO] de influência na máquina do estado, a capacidade da organização de ser um marco de referência política, ocorreram como resultado do Planafloro. A discussão em torno do projeto tem sido de importância fundamental para nós [...]. Como conseqüência das discussões em torno do Planafloro, a FETAGRO assimilou muito dos objetivos do projeto. A experiência do Planafloro e a nossa participação nela contribuíram muito para que reavaliássemos as nossas idéias, as ações da CONTAG [Confederação Nacional de Trabalhadores na Agricultura] [...]. Além disso, grupos ambientalistas que nunca haviam nos procurado, hoje sabem que nós lidamos com uma população que degrada o meio ambiente. No entanto, nós temos a capacidade de discutir isso com eles [...]. Os ambientalistas não conseguem trazer todos os interessados para dentro da discussão. Nós conseguimos."

A posição da FETAGRO é representativa de uma das grandes conquistas da rede transnacional de advocacia que se mobilizou em torno do Planafloro: a percepção crescente entre os grupos locais quanto ao vínculo existente entre a proteção ambiental e a sustentabilidade econômica. Ela é também indicativa de que a rede alcançou um dos seus principais objetivos: promover a participação de grupos de base no processo de formulação de políticas públicas no estado. A criação do Fórum de Rondônia em 1991 foi uma etapa crucial nesse curso. É interessante notar que quando o Fórum foi fundado, suas organizações filiadas consistiam em nove grupos de advocacia pública e organizações de apoio (ONGs de pesquisa) e dois grupos de base. Dez anos depois, as organizações de base filiadas ao Fórum somam 21 grupos, enquanto o número de entidades de apoio permanece praticamente constante (onze). É também relevante que, cada vez mais, o Fórum tem adotado o perfil de uma organização de mediação e facilitação de contatos e de distribuição de recursos entre as organizações de base da sociedade civil rondoniense. Nesse sentido, o Fórum tem restringido seu papel de iniciador ou catalisador de iniciativas de ativismo político e ambiental. Em outras palavras, hoje, o Fórum proporciona 


\section{Redes Transnacionais de Advocacia Pública:}

O Projeto Planafloro...

assistência legal ou recursos financeiros para pesquisa que venham a ser necessários para uma dada estratégia, por exemplo, uma ação civil pública. Quem inicia a estratégia, porém, é, em geral, uma organização de base, como a OSR ou a FETAGRO. No passado, tais iniciativas, apesar de contarem com o apoio de organizações de base, eram invariavelmente formuladas e empreendidas pela liderança do Fórum.

Ao concluir esta seção, é importante fazer duas perguntas: primeiramente, até que ponto a participação no Fórum de Rondônia e na rede transnacional de advocacia em torno do Planafloro levou a um aumento da capacidade política das organizações da sociedade civil rondoniense? Nos últimos dez anos, e em particular desde a apresentação do pedido de investigação do Planafloro ao Painel de Inspeção, as organizações rondonienses tornaram-se mais visíveis no cenário político local, viram crescer o número de seus afiliados, adquiriram conhecimentos relevantes sobre o modo de operação da burocracia estatal, ganharam acesso direto a determinadas agências estatais e com estas iniciaram diálogo produtivo, aumentaram sua capacidade técnica mediante a participação em iniciativas como a formulação do PAIC e o plano de zoneamento de Rondônia, e, finalmente, foram capazes de coordenar demandas comuns, a despeito de suas diferenças históricas, no que diz respeito a assuntos como o uso do solo e a criação de unidades de conservação. A segunda pergunta que se impõe é: até que ponto a participação dos grupos rondonienses em uma rede transnacional de advocacia socioambiental levou a um aumento de sua capacidade política de modo que, hoje, eles sejam capazes de fazer frente ao poder das elites econômicas locais e à tradição destas de manipulação dos recursos do estado em benefício próprio? A resposta a esta pergunta é, de modo geral, negativa. A despeito de conquistas isoladas em prol do meio ambiente em Rondônia, a participação dos grupos locais no ativismo transnacional que envolveu o Planafloro não foi suficiente para gerar um aumento de sua capacidade políti- 
ca a ponto de estes se tornarem capazes de opor resistência efetiva à tendência desenvolvimentista das forças políticas dominantes no estado. Nas conclusões, discuto alguns fatores que explicam as limitações políticas das organizações rondonienses e sugiro estratégias para que essas limitações sejam superadas.

\section{Conclusões}

Este artigo discutiu a estratégia de demandar uma investigação do projeto Planafloro ao Painel de Inspeção do Banco Mundial. Enfatizou-se o impacto disso sobre a capacidade política das organizações da sociedade civil rondoniense. A análise do processo de capacitação política de grupos locais no contexto de sua participação em uma rede transnacional de advocacia socioambiental questionou pressupostos teóricos importantes. O estudo da mobilização em torno do Planafloro demonstrou não só que o envolvimento em redes transnacionais de advocacia pode gerar um aumento relativo da capacitação política dos grupos locais, mas também desafios significativos à capacidade técnica destes. Tais desafios tendem, no longo prazo, a comprometer o espaço político conquistado pelas organizações locais no auge de seu envolvimento com a rede transnacional.

Como foi examinado, a estratégia de demandar a investigação do Planafloro produziu melhorias concretas na execução do projeto, mesmo levando-se em conta a rejeição do pedido de investigação pelo Conselho Executivo do Banco Mundial. Os efeitos dessa estratégia se fizeram sentir também no período que se seguiu à apresentação do pedido de investigação, o qual foi marcado por uma alteração na balança de poder em Rondônia, criando condições para a reformulação do Planafloro. A partir de 1996, recursos do projeto foram remanejados de modo a beneficiar seringueiros, populações indígenas e ribeirinhas e pequenos agricultores. 
Redes Transnacionais de Advocacia Pública: O Projeto Planafloro...

A despeito dessas conquistas, setores da sociedade civil rondoniense comprometidos com a proteção ambiental do estado têm encontrado dificuldades para enfrentar a ofensiva conservadora que passou a predominar na política local nos últimos anos. Tal ofensiva tem a ver com uma circunstância de desarticulação política entre os membros da rede transnacional de advocacia, e que é resultado de dois fatores inter-relacionados. Por um lado, os grupos locais, sobrecarregados pelas demandas técnicas de execução do PAIC, não tiveram como manter um monitoramento adequado de vários outros aspectos do Planafloro; por outro, o aumento das pressões sobre a capacidade técnica dos grupos locais acirrou tensões latentes entre eles, no que se refere aos objetivos e estratégias de participação no Planafloro e às políticas de desenvolvimento e preservação ambiental de Rondônia.

A perpetuação de uma limitada capacidade técnica e política das organizações rondonienses, a despeito de sua participação em uma rede transnacional de advocacia, evidencia-se de diversas formas. Como a maioria das organizações da sociedade civil, os grupos rondonienses não possuem recursos para pagar salários competitivos. Em consequiência, eles enfrentam uma crônica falta e/ou rotatividade de quadros qualificados. No caso específico do pedido de investigação, indivíduos que lideraram o processo adquiriram uma visibilidade que afetou (positivamente) suas oportunidades profissionais. Muitos deixaram suas organizações de origem para ocupar posições no governo federal junto a organizações nacionais e internacionais de apoio a movimentos sociais, e mesmo junto à equipe de execução do Planafloro. Aqueles que continuaram ligados aos grupos da sociedade civil comprometidos com a execução do PAIC e monitoramento do Planafloro tiveram que se desdobrar para cumprir funções que, freqüentemente, estavam além dos seus limites de tempo e recursos institucionais. Uma das atividades que ficaram extremamente comprometidas em decorrência da excessiva demanda sobre ativistas locais, foi a manutenção dos vínculos institucionais entre os grupos 
rondonienses e seus tradicionais aliados nacionais e internacionais. Ativistas locais negligenciaram atividades-chave nesse processo, tais como a manutenção dos canais de comunicação e troca de experiências (através de cartas, e-mails, participação em oficinas e conferências de interesse comum). O resultado de tudo isso é que os grupos rondonienses têm perdido oportunidades de fortalecer suas lutas via um engajamento mais profundo em iniciativas nacionais para a democratização da formulação das políticas públicas no Brasil.

A situação, portanto, é de uma ironia perversa: o sucesso de estratégias como a do pedido de investigação do Planafloro aumenta a demanda sobre os recursos políticos, técnicos e financeiros das organizações locais. Por causa da limitada capacidade destas, porém, esse acréscimo de demandas acaba por afetar a capacidade dos grupos locais de manter canais de cooperação com organizações nacionais e internacionais. Tais canais são justamente aqueles que poderiam oferecer os recursos necessários para o aumento da capacidade institucional dos grupos rondonienses. É aqui que o presente estudo dos processos que levaram ao pedido de investigação do Planafloro e de suas conseqüências oferece sua maior contribuição. Conforme vimos acima, fica evidente a importância de se prever o impacto de longo prazo que estratégias poderosas, como a de recorrer ao Painel de Inspeção, podem causar em contextos políticos locais. Torna-se fundamental que participantes de redes transnacionais de advocacia, nos planos local, nacional e internacional, estejam preparados para oferecer respostas às demandas que poderão advir do próprio sucesso de seu ativismo.

No caso da rede transnacional mobilizada em torno do Planafloro, nem as organizações rondonienses, nem os grupos internacionais que encorajaram o recurso ao Painel estavam preparados para abraçar as oportunidades decorrentes dessa estratégia ou para fazer frente aos desafios que esta gerou. Os grupos locais ainda tentaram, heroicamente, ocupar os espaços de participação na execução do Planaflo- 
Redes Transnacionais de Advocacia Pública: O Projeto Planafloro...

ro que emergiram em resposta ao pedido de investigação. Esses esforços, no entanto, esbarraram na baixa capacidade técnica e de recursos humanos dessas organizações. Já as ONGs internacionais negligenciaram as repercussões de longo prazo daquela estratégia sobre a política local devido, em parte, à prioridade dada à oportunidade de testar a eficácia do Painel de Inspeção. As ONGs internacionais partiram do pressuposto de que se tratava de um mero mecanismo de prestação de contas de um banco multilateral à sociedade civil global. Nesse sentido, elas ignoraram a natureza dinâmica desse mecanismo, negligenciando o fato de que o Painel é também uma arena transnacional de confronto entre forças que defendem modelos de desenvolvimento antagônicos. Ao deixarem de levar em conta este segundo aspecto da natureza do Painel, as ONGs internacionais interpretaram a rejeição do pedido de investigação do Planafloro como o fim de um processo promissor. Por conseguinte, elas ignoraram o fato de que tal rejeição não impediu o início de uma nova fase na luta pela adequada execução do Planafloro em Rondônia. O resultado dessa avaliação incompleta do impacto do pedido de investigação fez com que os grupos internacionais se distanciassem dos processos políticos que ocorreram em Rondônia após a rejeição do pedido. Quando as organizações rondonienses mais necessitavam da assistência técnica e política de seus aliados internacionais, de modo a fazer face às demandas decorrentes de sua participação no PAIC e no processo de zoneamento, esse apoio não se fez presente. $\mathrm{O}$ ativismo transnacional em torno do Planafloro ilustra de maneira inequívoca as dificuldades de institucionalização de parcerias transnacionais entre atores locais e globais. Nesse sentido, o caso contribui para fortalecer os argumentos de Fox (2000) sobre a fragilidade das redes de advocacia que envolvem, simultaneamente, ativistas nos países do Norte e do Sul.

É possível que o elemento-chave em processos de institucionalização de redes de advocacia envolvendo organizações do Norte e do 
Sul seja a mediação das organizações, ou rede de organizações, nacionais. Este "elo" foi sempre o mais fraco na rede transnacional mobilizada em torno do Planafloro. Em termos históricos, os grupos rondonienses tiveram acesso direto às ONGs internacionais interessadas na Amazônia, em grande parte devido à rede de contatos pessoais que foi estabelecida entre ativistas em Rondônia e no exterior desde o projeto Polonoroeste. No entanto, no correr dos dez anos que separaram os dois projetos, o Brasil passou por um processo de democratização política e social profundo. A sociedade civil brasileira criou diversos mecanismos que viabilizaram o aumento da participação popular nos processos de formulação de políticas públicas. Exemplos bem-sucedidos desses esforços são a "Rede Brasil sobre Instituições Financeiras Multilaterais" e o "Fórum Brasileiro de ONGs e Movimentos Sociais para o Meio Ambiente e Desenvolvimento". As organizações rondonienses, no entanto, têm sido uma ausência notável nesses mecanismos coletivos. Os desafios políticos locais e o peso dos compromissos que essas organizações assumiram no âmbito do Planafloro explicam, em parte, as dificuldades enfrentadas pelos grupos de Rondônia em estreitar seus vínculos com entidades de advocacia pública no plano nacional. No entanto, é essa mesma incapacidade que compromete a possibilidade de as organizações rondonienses se fortalecerem institucionalmente.

Outro aspecto do mesmo problema é a propensão que existe entre algumas ONGs internacionais de atrelarem a legitimidade de sua participação em determinados processos a alianças diretas com grupos ativistas locais. Freqüentemente, essa tendência faz com que grupos internacionais ignorem a mediação de mecanismos coletivos da sociedade civil estabelecidos nacionalmente. Entre as conseqüências desse procedimento estão inúmeras oportunidades perdidas por ONGs internacionais de ampliarem o alcance de seu ativismo. Em vez de investirem recursos em causas locais, ou de interesse de populações específicas, as ONGs internacionais poderiam também inves- 
Redes Transnacionais de Advocacia Pública: O Projeto Planafloro...

tir em causas nacionais, otimizando assim seu ativismo e direcionando-o para mudanças estruturais. Até que isso ocorra de modo sistemático, o sucesso de parcerias transnacionais entre grupos de advocacia do Norte e do Sul deverá continuar restrito a estratégias ou campanhas de impacto conjuntural.

(Recebido para publicação em janeiro de 2002)

\section{Notas}

1. O projeto Polonoroeste foi executado em dois estados amazônicos, Rondônia e Mato Grosso. Entre os seus objetivos estava promover a integração do Estado de Rondônia à economia nacional.

2. Os grupos da sociedade civil rondoniense não conseguiram impedir que o estado desviasse recursos da administração do Planafloro, e que tais desvios afetassem negativamente o desempenho do componente ambiental do projeto. A estratégia de pari passu, através da qual recursos para obras de infra-estrutura só seriam liberados em contraponto à execução de medidas de proteção ambiental, nunca foi eficaz.

3. Irei abordar o Painel de Inspeção no seu contexto institucional mais amplo, que inclui não apenas a equipe de especialistas responsável pelas investigações, mas também o Banco Mundial como instituição patrocinadora do Painel e o Comitê Executivo do Banco, instância decisória mais alta para assuntos relativos ao Painel. Nesse sentido, apesar de eu não questionar a neutralidade e idoneidade da equipe investigadora da instituição, cuja reputação é universalmente reconhecida e elogiada, questiono a neutralidade política do Painel enquanto mecanismo de prestação de contas à sociedade civil global.

4. "Comentários sobre a 'Segunda Revisão do Painel de Inspeção e o Esclarecimento de 1998 sobre Certos Aspectos da Resolução'”, 21/3/1999, www.ciel.org/bic6.

5. A estratégia visava fazer com que o Brasil se tornasse um candidato atraente para receber recursos internacionais para o meio ambiente que foram postos à disposição da comunidade internacional pelo G-7 na década de 80 . 


\section{Maria Guadalupe Moog Rodrigues}

6. Ver Rich (1994) e Le Prestre (1989) sobre as pressões institucionais impostas pelo Banco aos seus funcionários para que estes acelerassem o curso dos projetos pelas diversas etapas do ciclo de projeto (project cicle).

7. Os demais componentes do projeto eram: crédito rural e agroflorestal, transporte fluvial e terrestre, educação e saúde, e administração.

8. O Grupo de Trabalho, criado em 1984, é uma iniciativa conjunta do Banco e de ONGs de várias partes do globo que visa aumentar a capacidade de prestação de contas do Banco Mundial à sociedade civil global e a participação desta última nas operações do Banco. Detalhes sobre o envolvimento do GT com o projeto Planafloro foram obtidos a partir de entrevista com ex-funcionário, em fevereiro de 2001.

9. Na realidade, como explica a autora, as elites políticas de Rondônia manobraram de modo a dar às ONGs locais um papel proeminente em termos simbólicos, mas completamente irrelevante em termos políticos.

10. Millikan (1998) e entrevistas com Breno, consultor do Fórum de Rondônia, novembro de 1994 e maio de 2000.

11. Entrevista com ex-funcionário do Grupo de Trabalho, fevereiro de 2001.

12. A inclusão de organizações da sociedade civil rondoniense no Conselho Deliberativo foi uma resposta tanto do Banco quanto do governo de Rondônia a pressões pela criação de um espaço de participação popular no projeto. Essa resposta foi formalizada através de um Protocolo de Entendimento firmado em 20 de junho de 1991 entre o governador de Rondônia e doze organizações da sociedade civil local.

13. Carta do Fórum de ONGs de Rondônia ao Banco Mundial, de 15/6/1994.

14. Keck (1998) enfatiza a força da política clientelista em Rondônia e explica que o interesse das elites políticas rondonienses no Planafloro nunca esteve relacionado aos potenciais benefícios ambientais que o projeto traria ao estado. Ao contrário, as elites políticas esperavam que o projeto fosse apenas uma fonte confiável de recursos externos a serem distribuídos em forma de benefícios a seus aliados. É importante lembrar que os recursos do Planafloro chegaram a Rondônia em uma época em que recursos federais e demais linhas de crédito ao estado estavam praticamente interrompidos.

15. Carta do Banco Mundial ao ministro da Economia e Planejamento do Brasil, Marcílio Marques Moreira, de 22/6/1992; Carta do Fórum de ONGs de Rondônia ao presidente da República do Brasil e ao ministro da Economia e Planejamento, de 29/5/1992; e cartas do Fórum de ONGs de Rondônia ao presidente do INCRA, de 29/5/1992, 14/8/1992, 8/9/1992, 28/2/1993 e 15/4/1993. 
Redes Transnacionais de Advocacia Pública: O Projeto Planafloro...

16. A liderança dessas organizações adotou uma postura crítica com relação à abordagem estrutural do Banco sobre o processo de desenvolvimento e também à aliança que se constituiu "de fato" entre este e o governo de Rondônia. No entanto, em termos pragmáticos e imediatos, a capacidade adquirida pelas lideranças da sociedade civil de dialogar com empregados do Banco em pé de igualdade garantiu-lhes uma visibilidade política que passou a ser reconhecida pelo governo do estado.

17. A Campanha MDB foi organizada em meados dos anos 80 por ONGs internacionais de meio ambiente lideradas por grupos norte-americanos. A Campanha visava fazer com que os Bancos se responsabilizassem por prestar contas à sociedade civil global dos custos sociais e ambientais impostos por seus projetos de desenvolvimento. Entre as estratégias da Campanha MDB constavam audiências públicas no Congresso americano e no Parlamento europeu, a mobilização da mídia e campanhas baseadas em abaixo-assinados e cartas-denúncia.

18. Entrevista com Paulo, funcionário do Fórum de Rondônia, Porto Velho, novembro de 1994.

19. Carta do Fórum de ONGs e Movimentos Sociais de Rondônia ao Banco Mundial, de 15/6/1994.

20. Entrevista com Estevão, ativista ambiental em uma $O N G$ internacional de meio ambiente sediada em Washington, D.C., março de 2001. Setores da mídia rondoniense também interpretaram a vinda da missão do Banco em agosto de 1994 como uma etapa preparatória do processo de suspensão de desembolsos para o projeto (O Progresso, 5/8/1994, Rolim de Moura, Rondônia).

21. Respectivamente, entrevistas com o seringueiro Sílvio, maio de 2000, e com Paco, ex-funcionário da Comissão Pastoral da Terra (CPT), novembro de 1994, Rondônia.

22. Entrevista com Fernando, ex-secretário executivo do Fórum de Rondônia, março de 1995, Brasília.

23. Entrevista com Fernando, ex-secretário executivo do Fórum de Rondônia, março de 1995, Brasília.

24. Aqui é importante sublinhar o papel desempenhado pelas ONGs internacionais no processo de encaminhamento do Planafloro ao Painel de Inspeção. Quando eu estive com Brent Millikan, um dos principais autores do documento de 81 páginas que detalhava as razões para o pedido de investigação, em março de 1995, em Brasília, ele já estava trabalhando na pesquisa que daria fundamento ao pedido, juntamente com Roberto Smeraldi, da FoE. Nessa mesma ocasião, porém, o secretário executivo do Fórum afirmou não haver envolvimento algum 


\section{Maria Guadalupe Moog Rodrigues}

do Fórum com o processo, além do conhecimento de que este estava nas mãos de Millikan e Smeraldi.

25. Entrevistas com Eduardo, funcionário da organização Amigos da Terra, Programa Amazônia, maio de 2000, São Paulo, com Fernando, ex-secretário executivo do Fórum de Rondônia, maio de 2000, Rondônia, e com João Batista, funcionário da ONG brasileira FASE, dezembro de 2000.

26. Fórum das ONGs e Movimentos Sociais que Atuam em Rondônia e Friends of the Earth/Amigos da Terra, Programa Amazônia, Request for Inspection Submitted to the World Bank Inspection Panel on the Planafloro-Rondônia Natural Resources Management Project, Porto Velho, 25/7/1995, p. 10.

27. O pedido também denunciou a negligência do Banco em monitorar a administração do Planafloro e os investimentos em programas de marketing.

28. Fórum das ONGs e Movimentos Sociais que Atuam em Rondônia e Friends of the Earth/Amigos da Terra, Programa Amazônia, Request for Inspection Submitted to the World Bank Inspection Panel on the Planafloro-Rondônia Natural Resources Management Project, Porto Velho, 25/7/1995, p. 5.

29. Isso se tornara uma necessidade política já que o número de organizações de base filiadas ao Fórum havia passado de dois, em 1991, a treze, em 1995, enquanto o número de ONGs de apoio e advocacia havia permanecido praticamente o mesmo (entre nove e doze).

30. Entrevista com Olavo, ex-funcionário da Rede Brasil, maio de 2000, Brasília.

31. Entrevista com Sérgio, membro da equipe de administração do Planafloro no Banco Mundial, junho de 2000, Cuiabá.

32. Entrevista com Fernando, ex-secretário executivo do Fórum de Rondônia, maio de 2000, Rondônia.

33. Entrevista com Breno, consultor do Fórum de Rondônia, maio de 2000.

34. Os diretores executivos representando países do Norte, com exceção dos da França e do Reino Unido, apoiaram o pedido de investigação do Planafloro. Os representantes dos países do Sul, liderados por uma coalizão de diretores do Brasil, Índia e China, opuseram-se à investigação.

35. www.ciel.org/planafl2.html, p. 7.

36. Entrevista com Fernando, ex-secretário executivo do Fórum de Rondônia, maio de 2000, Rondônia. 


\section{Redes Transnacionais de Advocacia Pública: O Projeto Planafloro...}

37. Isso abriu dois precedentes que vieram a afetar a eficácia do Painel em pedidos de investigação subseqüentes. Em primeiro lugar, os Planos de Ação tornaram-se alternativa rotineira a uma investigação completa pelo Painel. Em conseqüência, em vez de terem suas denúncias investigadas por uma equipe independente, os demandantes são forçados a aceitar uma solução criada pelos próprios atores que deram origem aos problemas em questão. Em segundo lugar, a rejeição do pedido de investigação do Planafloro deu novo ímpeto aos esforços de um grupo de diretores executivos, liderados por Paiva, no sentido de iniciar procedimentos que limitassem o mandato do Painel. No contexto da Revisão do Painel de Inspeção em 1999, o Brasil patrocinou uma proposta para que fossem julgados improcedentes pedidos de investigação cujas acusações se referissem à ausência de benefícios às populações-alvo. De acordo com a referida proposta, o Painel deveria se restringir à investigação de projetos acusados de terem gerado prejuízos concretos a indivíduos ou comunidades (para maiores detalhes, ver www.ciel.org/planafl2.html).

38. “Cronograma dos Fatos", Notícias do Fórum, ano 3, nำ 4, dezembro de 1995.

39. "Banco Mundial Tenta Evitar a Denúncia", Notícias do Fórum, ano 3, no 4, dezembro de 1995.

40. Entrevistas com Estevão, ativista ambiental, e Sérgio, membro da equipe de administração do Planafloro no Banco Mundial.

41. Entrevistas com Sérgio, membro da equipe de administração do Planafloro no Banco Mundial, e com Davi, funcionário do Banco Mundial na missão brasileira, maio de 2000, Brasília.

42. Entrevista com Davi, funcionário do Banco Mundial na missão brasileira, maio de 2000, Brasília.

43. Entrevista com Davi, funcionário do Banco Mundial na missão brasileira, maio de 2000, Brasília.

44. Entrevista com Fernando, ex-secretário executivo do Fórum de Rondônia, maio de 2000, Rondônia.

45. Muitos observadores poderão discordar desta afirmação com base no fato de que os recursos do PAIC levaram muito tempo para atingir - quando atingiram de fato - seus beneficiários. Ainda que eu concorde com essa crítica, é importante ressaltar que, dado o volume de recursos disponíveis para o programa, a porcentagem destes que efetivamente chegou às comunidades rondonienses não pode ser negligenciada. Isso é particularmente verdade quando se discutem os "novos PAICs" cujos desembolsos foram iniciados em 2000. 


\section{Maria Guadalupe Moog Rodrigues}

46. Browder propôs a revisão de uma série de diretrizes para a aprovação de novos PAICs. Estas deveriam tentar resolver problemas como a falta de integração funcional entre os diferentes aspectos das propostas apresentadas e os baixos níveis de parceria entre as organizações beneficiadas e outras instituições, particularmente os governos locais. O objetivo da reformulação proposta era evitar que os PAICs acabassem por substituir investimentos públicos.

47. O governador Raupp pôde realizar tal manobra devido ao sistema de desembolsos do PAIC. De acordo com os estatutos do Banco Mundial, seus recursos só podem ser transferidos para contas governamentais (no caso, o governo de Rondônia). Durante o processo de formulação do PAIC, porém, as ONGs pleitearam que as organizações beneficiadas tivessem controle direto sobre os recursos. A solução encontrada foi a criação de contas conjuntas entre o governo do estado e a organização a ser beneficiada pelo PAIC. No final de 1998, muitas das organizações beneficiadas já haviam confirmado o depósito dos recursos nas suas contas conjuntas. Não foi pequena a surpresa quando estas vieram a descobrir que o estado havia retirado o montante sem lhes dar qualquer aviso prévio.

48. Entrevista com Breno, consultar do Fórum de Rondônia, maio de 2000, Brasília.

49. Entrevista com o seringueiro Sílvio, maio de 2000, Rondônia.

50. Conversa pelo telefone com o seringueiro Sílvio, 12/4/2001.

51. O artigo 13 da Lei $n-233$ (a Lei de Zoneamento) autoriza o desmatamento de até $80 \%$ da cobertura florestal na subárea 1.1, definida como densamente povoada e adequada para produção agrícola e agropastoril. Essa disposição contraria a lei maior, o Código Florestal Nacional, que estabelece um teto máximo de 50\% para o desmatamento. A aprovação da Lei nº 233, em Rondônia, dá munição aos setores conservadores no Congresso Nacional brasileiro que têm tentado - até agora sem sucesso - aumentar o limite permitido para o desmatamento previsto pelo Código Florestal. 


\section{Redes Transnacionais de Advocacia Pública: O Projeto Planafloro...}

\section{Referências Bibliográficas}

BROWDER, John. (1998), Report - World Bank Mid-Term Supervision Mission for the Program of Support to Community Initiatives (PAIC), Planafloro (loan 3444-BR), 20 de novembro-3 de dezembro. Manuscrito.

COMAI (Comitê de Avaliação Independente). (s/d), Plano Agropecuário e Florestal de Rondônia - Planafloro. Relatório de Avaliação. Manuscrito.

FOX, Jonathan. (2000), Assessing Binational Civil Society Coalitions: Lessons from the Mexico-US Experience. Trabalho apresentado no Encontro da Associação para Estudos Latino-Americanos, Miami, Florida, 16-18 de março.

HUNTER, David. (s/d), "The Planafloro Claim: Lessons from the Second World Bank Inspection Panel Claim”. www. ciel. org/planfl2.

JEZIC, Tamara. (2001), "Ecuador: The Campaign against Texaco Oil", in D. Cohen, R. Vega e G. Watson (eds.), Advocacy for Social Justice-A Global Action and Reflection Guide. Bloomfield, CT, Kumarian Press.

JORDAN, Lisa e VAN TUIJL, Peter. (2000), "Political Responsibility in Transnational NGO Advocacy”. World Development, vol. 28, n12, pp. 2051-2065.

KECK, Margaret. (1998), "Planafloro in Rondonia: The Limits of Leverage", in J. A. Fox e D. L. Brown (eds.), The Struggle for Accountability - The World Bank, NGOs, and Grassroots Movements. Cambridge, MA/London, The MIT Press, pp. 181-218.

e SIKKINK, Kathryn. (1998), Activists beyond Borders - Advocacy Networks in International Politics. Ithaca/London, Cornell University Press.

LE PRESTRE, Phillip. (1989), The World Bank and the Environmental Challenge. London, Susquehanna University Press.

LIPSCHUTZ, Ronnie e MAYER, Judith. (1996), Global Civil Society and Global Environmental Governance - The Politics of Nature from Place to Planet. Albany, NY, State University of New York Press.

MILLIKAN, Brent. (1998), "Planafloro, Modelo de Projeto Participativo", in J. P. Leroy e M. C. Soares (orgs.), Bancos Multilaterais e Desenvolvimento Participativo no Brasil. Rio de Janeiro, FASE/IBASE. 
. (2001), "O Painel de Inspeção do Banco Mundial e o Pedido de Investigação sobre o Planafloro", in A. Vianna Jr. et alii (orgs.), Banco Mundial: Participação, Transparência e Responsabilidade: A Experiência Brasileira com o Painel de Inspeção. Brasília, Rede Brasil.

O'BRIEN, R., GOETZ, A., SCHOLTE, J. e WILLIAMS, M. (2000), Contesting Global Governance - Multilateral Economic Institutions and Global Social Movements. Cambridge, Cambridge University Press.

PRINCEN, Thomas. (1994), "NGOs: Creating a Niche in Environmental Diplomacy", in T. Princen e M. Finger. Environmental NGOs in World Politics Linking the Local and the Global. London/New York, Routledge.

RICH, Bruce. (1994), Mortgaging the Earth - The World Bank, Environmental Impoverishment, and the Crisis of Development. Boston, Beacon Press.

RODRIGUES, Maria. (2000), "Environmental Protection Issue Networks in Brazil's Amazonia". Latin American Research Review, vol. 35, no 3, pp. 125-153.

ROSENAU, James. (1993), "Environmental Challenges in a Turbulent World", in R. Lipschutz e K. Conca (eds.), The State and Social Power in Global Environmental Politics. New York, Columbia University Press.

SMERALDI, Roberto e MILLIKAN, Brent. (1997), Planafloro - Um Ano Depois - Análise Crítica da Implementação do Plano Agropecuário e Florestal de Rondônia Um Ano após o Acordo para a sua Reformulação. Amigos da Terra Internacional - Programa Amazônia e Oxfam, São Paulo / Porto Velho, agosto. Manuscrito. 


\title{
Resumo
}

\section{Redes Transnacionais de Advocacia Pública: Estratégias e Impactos - O Projeto Planafloro e o Painel de Inspeção do Banco Mundial}

\begin{abstract}
O projeto Planafloro, financiado pelo Banco Mundial em Rondônia durante os anos 90, tinha como objetivo principal o manejo dos recursos naturais no estado. A incapacidade e falta de vontade política dos órgãos executores motivaram organizações da sociedade civil rondoniense a pedir a investigação do Planafloro pelo Painel de Inspeção. O painel é um mecanismo independente de prestação de contas à sociedade civil global no que se refere às políticas e procedimentos do Banco Mundial. As estratégias de mobilização que culminaram no pedido de investigação do Planafloro se processaram em um contexto de ativismo socioambiental orquestrado por uma rede transnacional de advocacia pública. O pressuposto teórico dominante na literatura sobre redes transnacionais de advocacia pública é que a participação de grupos locais nessas redes proporciona um aumento relativo da capacidade política destes. O caso do Planafloro revela, no entanto, que a participação de grupos locais em redes transnacionais acarreta, além do aumento relativo de sua capacidade política, novas responsabilidades e desafios que estes nem sempre estão preparados para enfrentar. No longo prazo, esse despreparo pode comprometer os eventuais ganhos políticos conquistados pelos grupos locais no âmbito da mobilização transnacional.
\end{abstract}

Palavras-chave: Painel de Inspeção - Planafloro - Banco Mundial - Redes Transnacionais 


\section{Abstract}

\section{Transnational Advocacy Networks: Strategies and Impact - The Planafloro Project and the World Bank's Inspection Panel}

The Planafloro project, funded by the World Bank in Rondônia during the nineties had as its main objective the management of the state's natural resources. The lack of capacity and of political will of implementing agencies eventually led Rondonian civil society organizations to request the investigation of Planafloro by the Inspection Panel. The panel is an accountability mechanism of the global civil society that oversees certain policies and procedures by the World Bank. The strategies that climaxed in the request for investigation of Planafloro unfolded in a context of social and environmental activism orchestrated by a transnational public advocacy network. The dominant assumption in the literature is that the participation of local groups in transnational advocacy networks contributes to a relative increase of their political capacity. The case of Planafloro reveals that local groups' participation in transnational networks, while increasing their political weight, entails new responsibilities and challenges that they are not always ready to shoulder. In the long term, this fragility may compromise political gains.

Key words: Inspection Panel - World Bank - Transnational Network Planafloro 